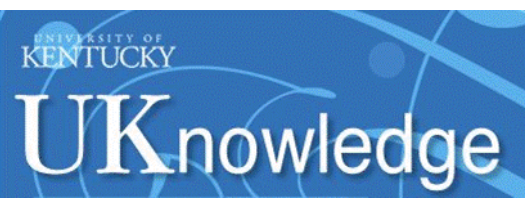

University of Kentucky

UKnowledge

\title{
Cloning and Developmental Expression of Pea Ribulose-1,5-Bisphosphate Carboxylase/Oxygenase Large Subunit N-Methyltransferase
}

Robert L. Houtz

University of Kentucky, rhoutz@uky.edu

Follow this and additional works at: https://uknowledge.uky.edu/horticulture_patents

Part of the Horticulture Commons

Right click to open a feedback form in a new tab to let us know how this document benefits you.

\section{Recommended Citation}

Houtz, Robert L., "Cloning and Developmental Expression of Pea Ribulose-1,5-Bisphosphate Carboxylase/ Oxygenase Large Subunit N-Methyltransferase" (1998). Horticulture Faculty Patents. 9.

https://uknowledge.uky.edu/horticulture_patents/9

This Patent is brought to you for free and open access by the Horticulture at UKnowledge. It has been accepted for inclusion in Horticulture Faculty Patents by an authorized administrator of UKnowledge. For more information, please contact UKnowledge@lsv.uky.edu. 


\section{United States Patent}

[19]
USO05723752A

[11] Patent Number:

$5,723,752$

[45] Date of Patent:

Mar. 3, 1998
[54] CLONING AND DEVELOPMENTAL EXPRESSION OF PEA RIBULOSE-1,5BISPHOSPHATE CARBOXYLASE/ OXYGENASE LARGE SUBUNIT NMETHYLTRANSFERASE

[75] Inventor: Robert L. Houtz, Lexington, Ky.

[73] Assignee: University Of Kentucky, Lexington, Ky.

[21] Appl. No.: 391,000

[22] Filed: Feb. 21, 1995

[51] Int. $\mathrm{Cl}^{6}$ A01H 5/00; C12N 15/29; C12N 15/54; C12N 15/82

[52] U.S. C1. 800/205; 800/DIG. 18 800/DIG. 19; 800/DIG. 23; 800/DIG. 26; 800/DIG. 40; 800/DIG. 41; 800/DIG. 42; 800/DIG. $43 ; 800 /$ DIG. $44 ; 536 / 23.2 ; 536 / 23.6$; $435 / 69.1 ; 435 / 70.1 ; 435 / 172.3 ; 435 / 193$;

$435 / 320.1$

[58] Field of Search $536 / 23.2,23.6$ $435 / 69.1,70.1 .172 .3,320.1,193 ; 800 / 205$. DIG. $18,19.23,26.40-44$

\section{References Cited}

\section{PUBLICATIONS}

Black et al., "Light-Regulated Methylation of Chloroplast Proteins". The Journal of Biological Chemistry, vol. 262, No. 20. Jul. 15, 1987, pp. 9803-9807.

Houtz et al.. "Affinity Purification of Ribulose-1-5-Bisphosphate Carboxlase/Oxygenase Large Subunit $\in \mathrm{N}-$ Methyltransferase". Supplement to Plant Physiology. Aug. 1992. Abstract No. 343, vol. 99 Suppl. 1. Houtz et al. "Identification and Specificity Studies of Ribulose-1.5-Bisphosphate Carboxylase/Oxygenase Large Subunit $\in \mathbb{N}-$ Methyltransferase". Supplement to Plant Physiology. Aug. 1992, Abstract No. 344. vol. 99 Suppl. 1.

Houtz et al.. "Partial Amino Acid Sequence of Ribulose-1. 5-Bisphosphate Carboxlase/Oxgenase Large Subunit $\in$ N-Methyl Transferase". Supplement to Plant Physiology. vol. 102. No. 1, May 1993, Abstract No. 248.

Houtz et al.. "Partial Purification and Characterization of Ribulose-1,5-bisphosphate Carboxlase/Oxygenase Large Subunit $\in$ N-Methyltransferase". Plant Physiol. vol. 97 No. 3, 1991, pp. 913-920
Klein et al., "Cloning and Expression of the Rubisco Large Subunit Methyl-Transferase Gene from Pea". Supplement to Plant Physiology, vol. 105. May 1994. Abstract No. 438.

Niemi et al., "Protein Methylation in Pea Chloroplast", Plant Physiol.. vol. 93, 1990, pp. 1235-1240.

Houtz et al.. "Posttranslational Modifications in the Amino-Terminal Region of the Large Subunit of Ribulose-1, 5-Bisphosphate Carboxylase/Oxygenase from Several Plant Species," Plant Physiol., 98:1170-74 (1992).

Mulligan et al., "Reaction-Intermediate Analogue Binding by Ribulose Bisphosphate Carboxylase/Oxygenase Causes Specific Changes in Proteolytic Sensitivity: The Amino-Terminal Residue of the Large Subunit is Acetylated Proline." Proc. Natl. Acad. Sci. USA.85:1513-17 (Mar. 1988).

Houtz et al., "Post-Translational Modifications in the Large Subunit of Ribulose Bisphosphate Carboxylase/Oxygenase," Proc. Natl. Acad. Sci. USA, 86:1855-1859 (Mar. 1989).

Napoli et al. 1990. Plant Cell 2:279-289.

Smith et al. 1988. Nature 334:724-726.

Klein et al. 1993. Planta 190(4): 498-510.

Eckes et al. 1986. Mol. Gen. Genet. 205:14-22.

Primary Examiner-David T. Fox

Attomey, Agent, or Firm-Burns, Doane. Swecker \& Mathis, L.L.P.

[57]

\section{ABSTRACT}

The gene sequence for ribulose-1.5-bisphosphate carboxylase/oxygenase (Rubisco) large subunit (LS) $\in N$-methyltransferase (protein methylase III or Rubisco LSMT) is disclosed. This enzyme catalyzes methylation of the $\epsilon$-amine of lysine-14 in the large subunit of Rubisco. In addition, a full-length cDNA clone for Rubisco LSMT is disclosed. Transgenic plants and methods of producing same which (1) have the Rubisco LSMT gene inserted into the DNA, and (2) have the Rubisco LSMT gene product or the action of the gene product deleted from the DNA are also provided. Further, methods of using the gene to selectively deliver desired agents to a plant are also disclosed.

15 Claims, 4 Drawing Sheets 

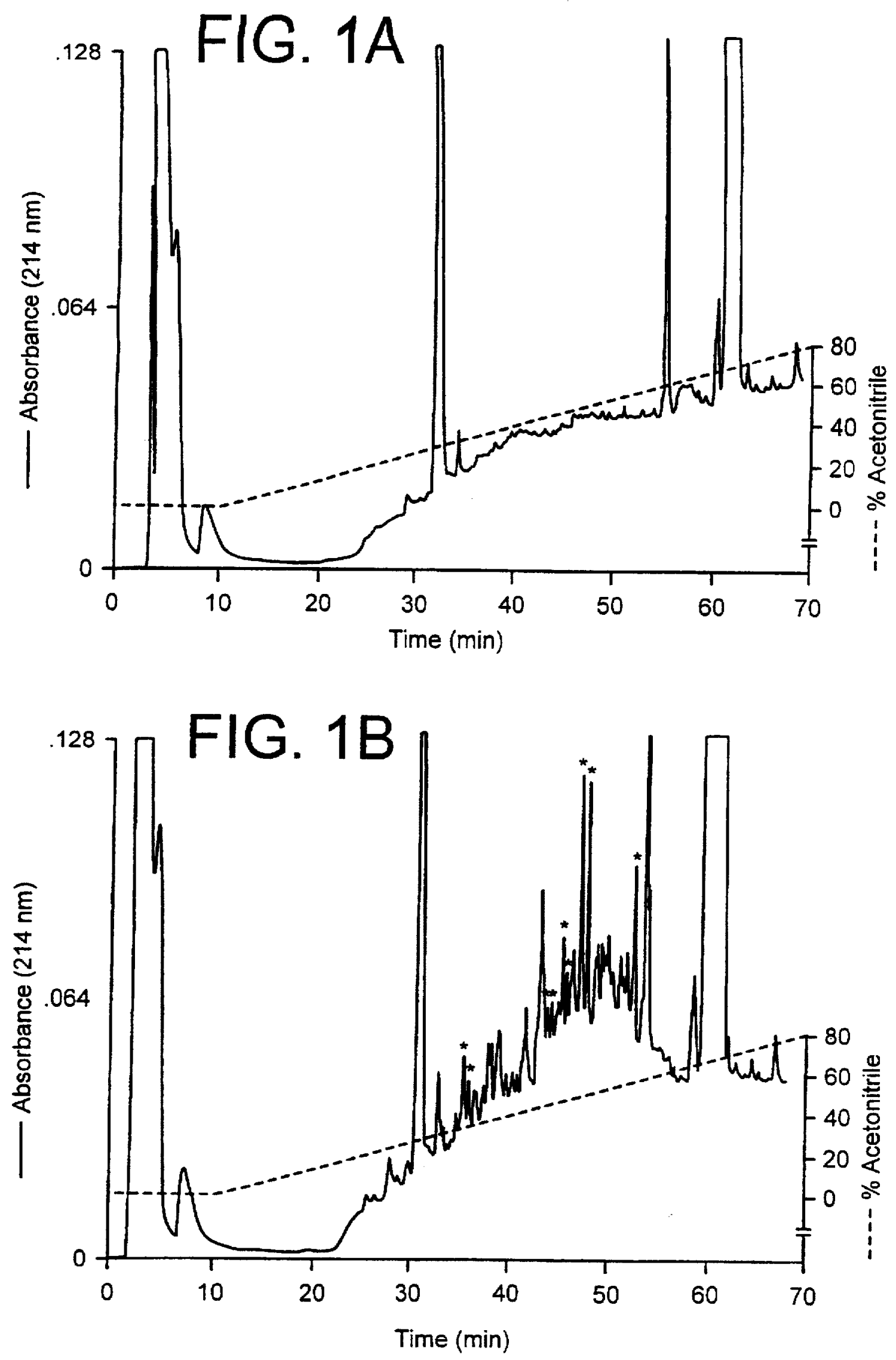


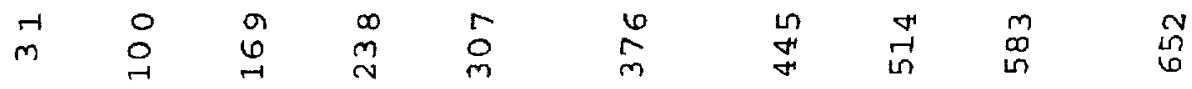

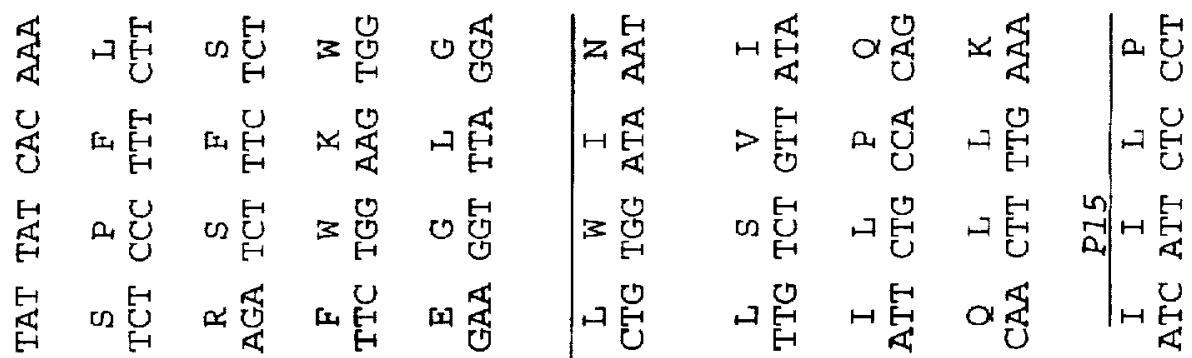

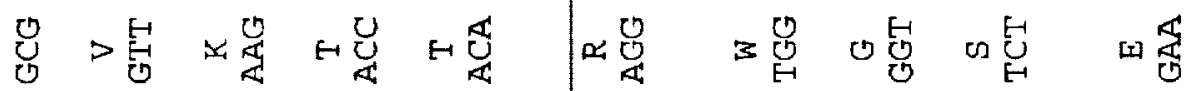

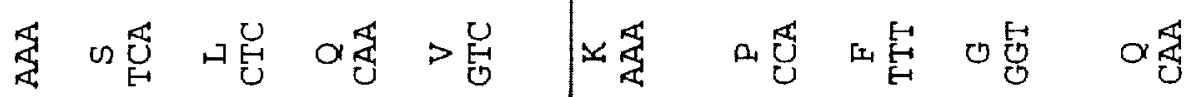

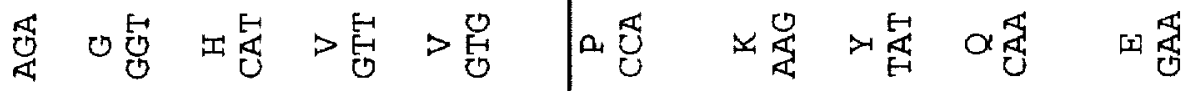

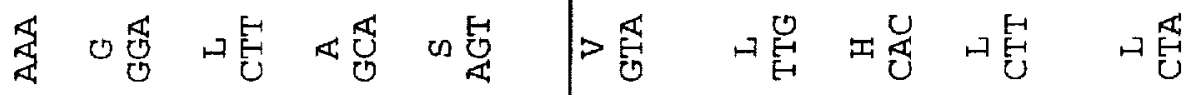

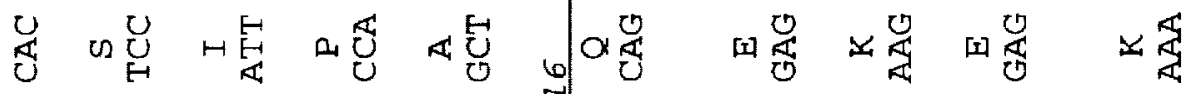

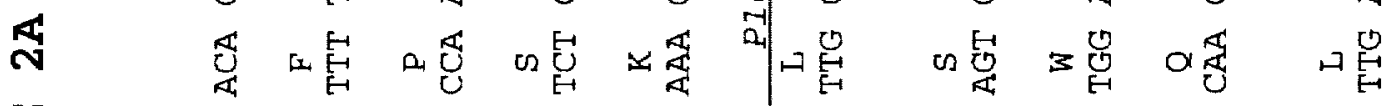

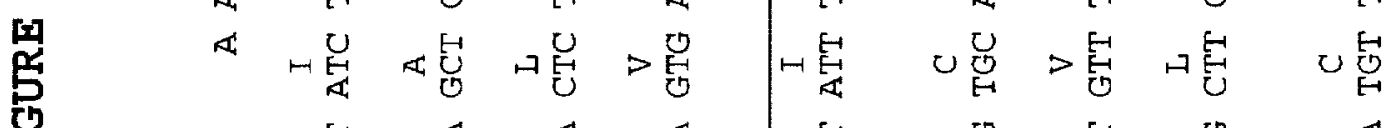

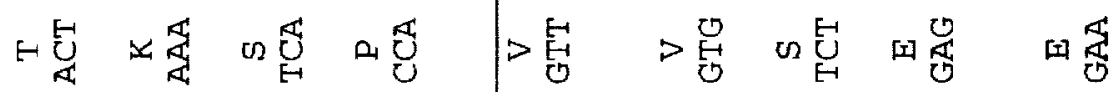

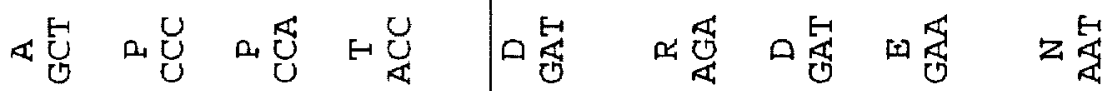

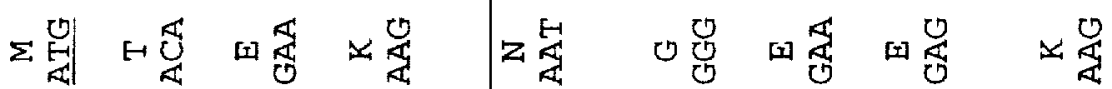

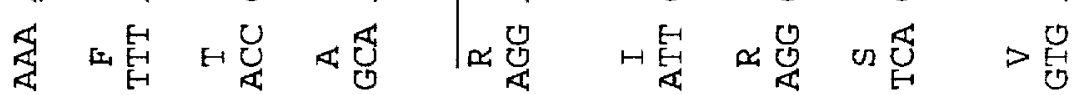

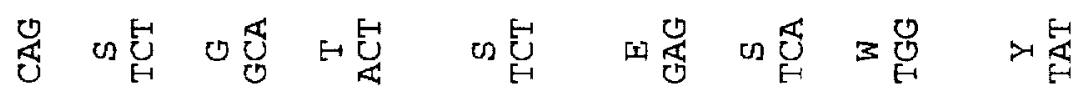

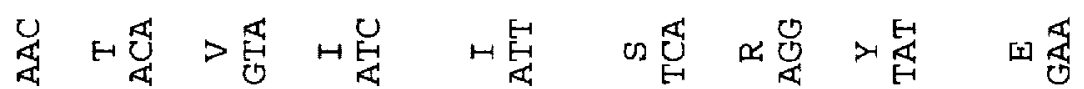

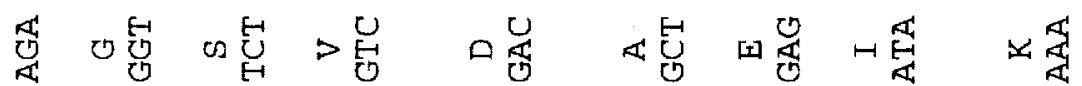

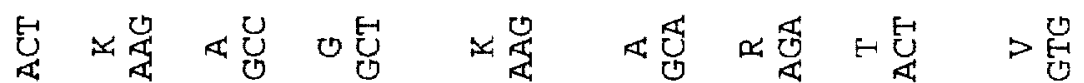

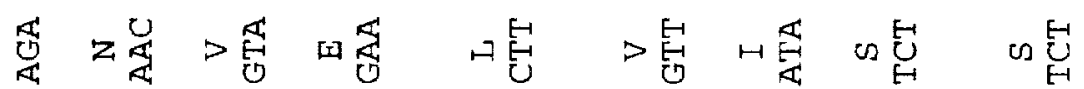

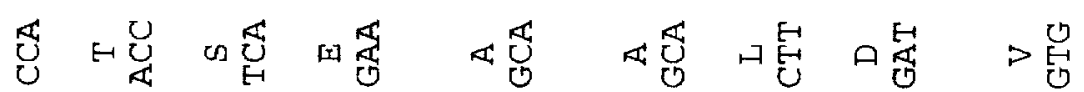

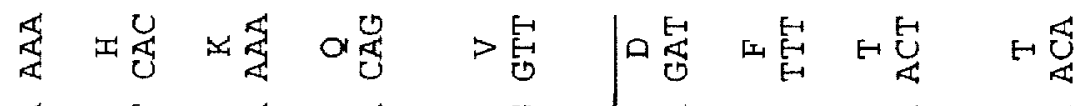

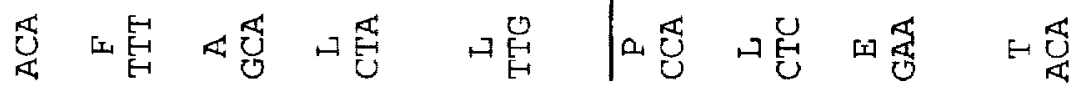




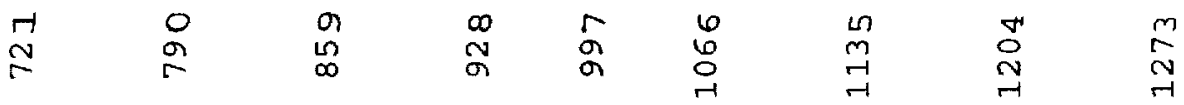

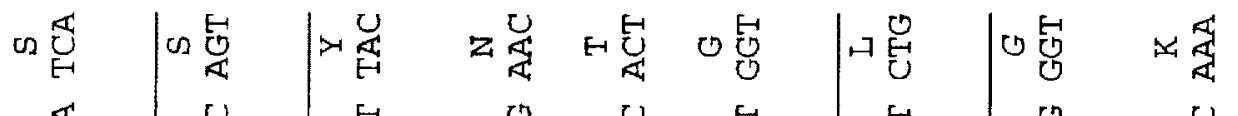

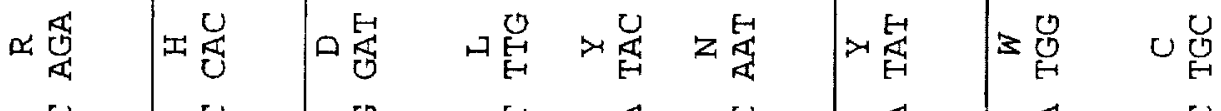

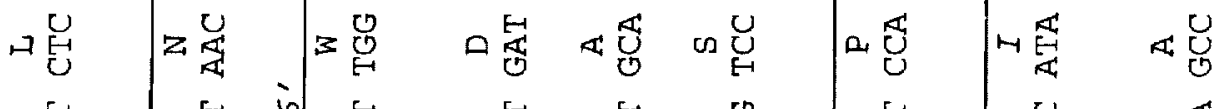

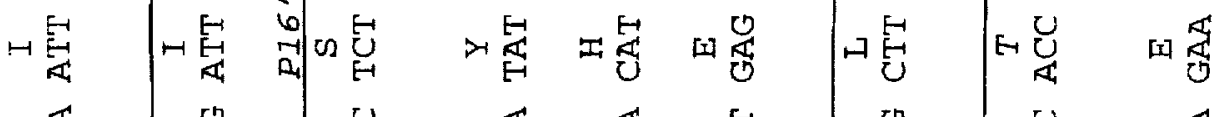

0忽

山舅 口否

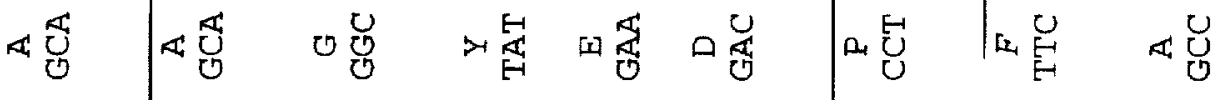

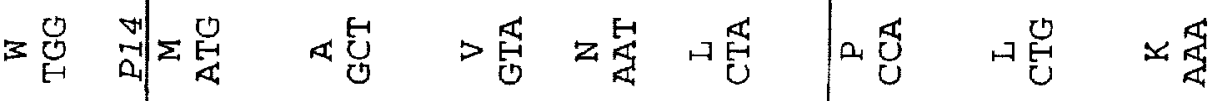

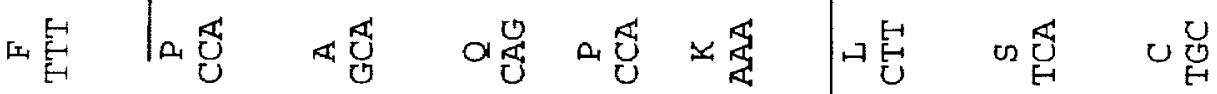

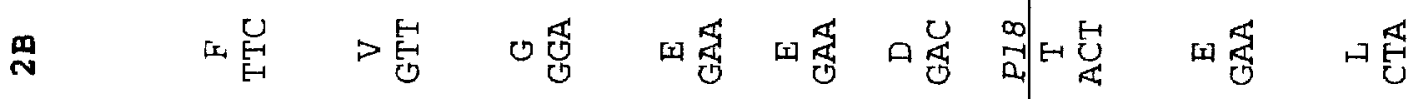

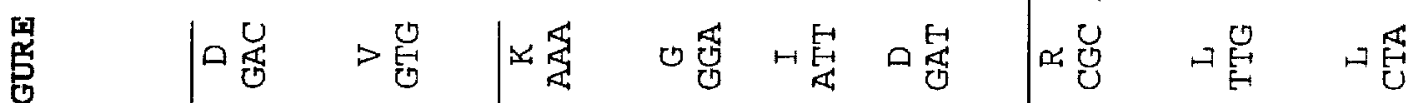

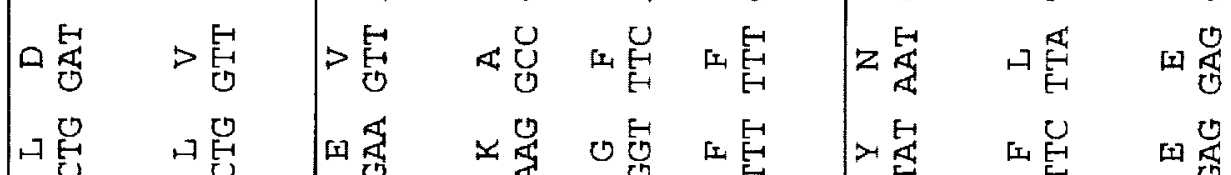

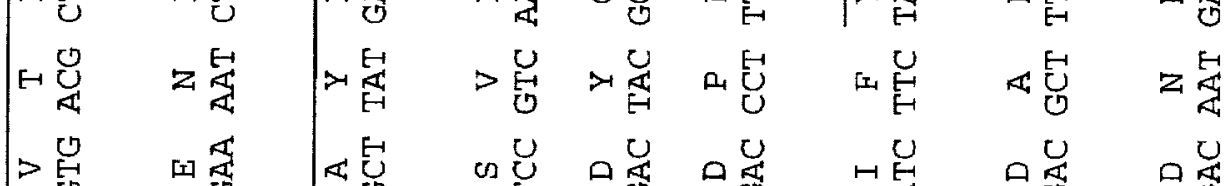

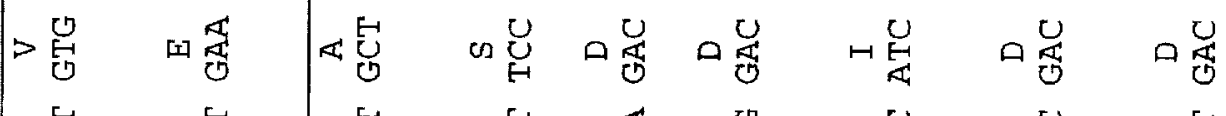

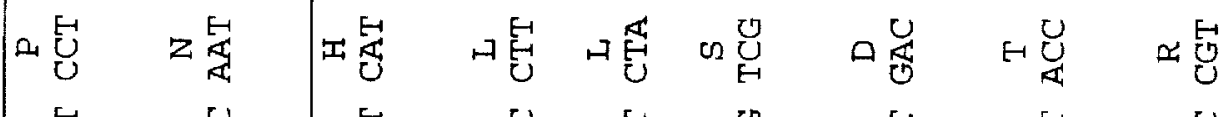

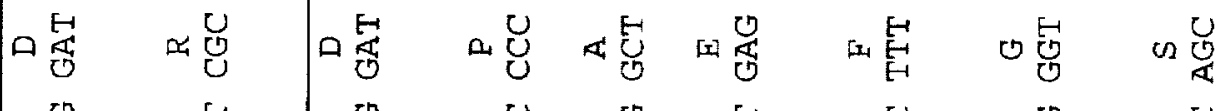

a导樭

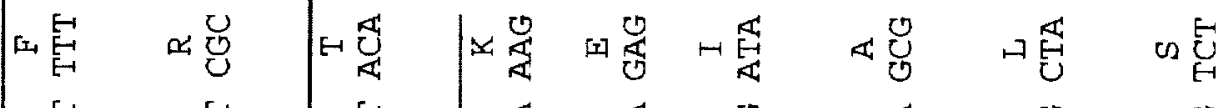

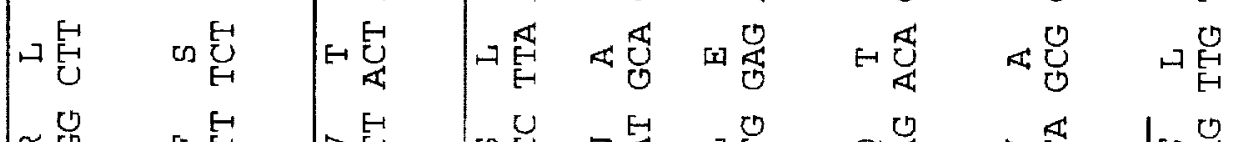

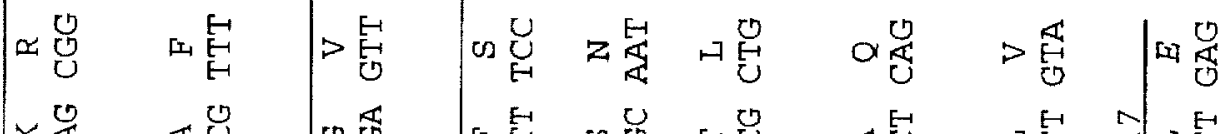

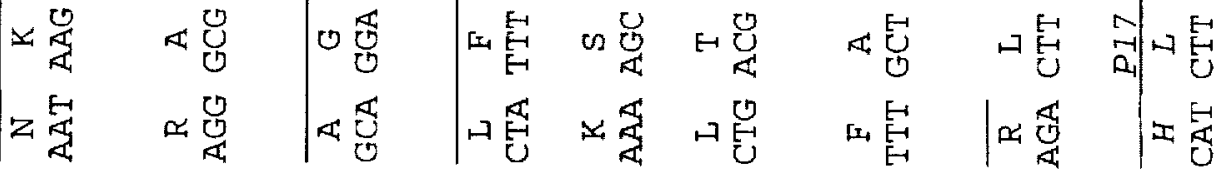




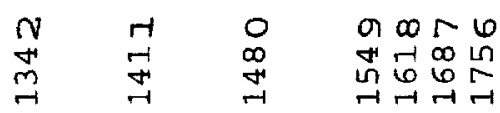

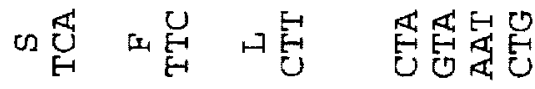

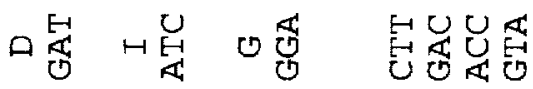

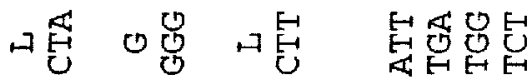

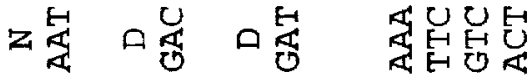

鸟

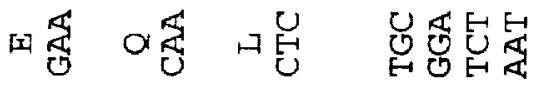

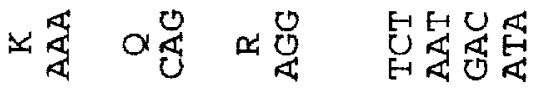

小导

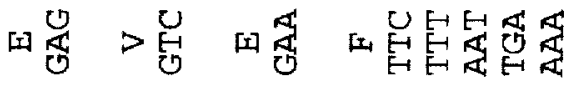

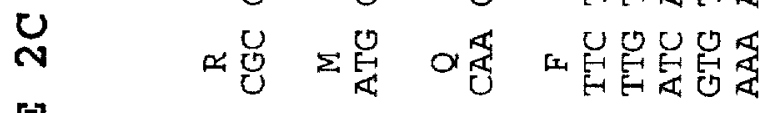

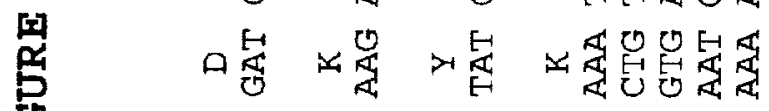

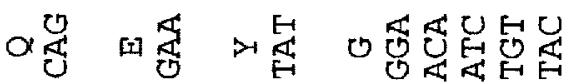

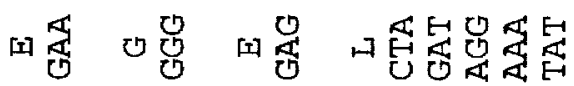

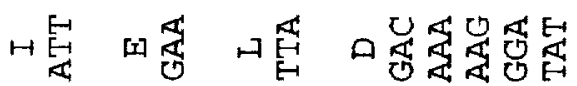

世导

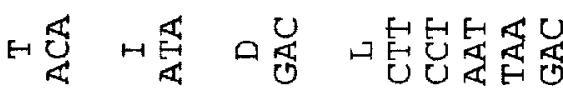

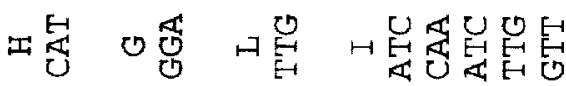

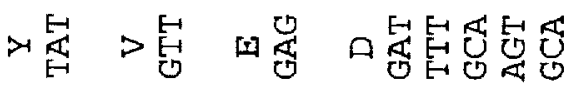

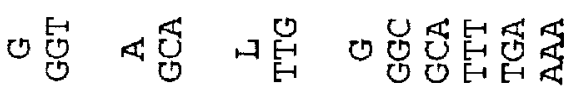

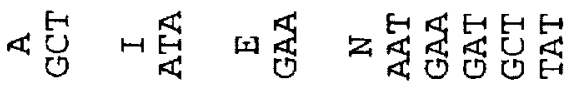

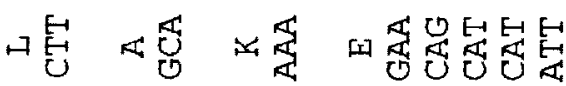

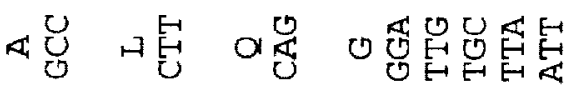

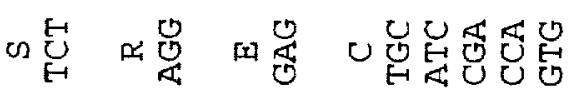


1

CLONING AND DEVELOPMENTAL EXPRESSION OF PEA RIBULOSE-1,5BISPHOSPHATE CARBOXYLASE/ OXYGENASE LARGE SUBUNIT $N$ METHYLTRANSFERASE

\section{IDENTIFICATION OF FEDERAL FUNDING}

The present invention was supported by U.S. Department of Energy Grant DE-FG05-92ER20075.

\section{BACKGROUND OF THE INVENTION}

\section{Field of the Invention}

The present invention relates to ribulose-1.5-bisphosphate carboxylase/oxygenase (Rubisco) large subunit (LS) $\in \mathrm{N}$-methyltransferase (protein methylase III or Rubisco LSMT). This enzyme catalyzes methylation of the $\epsilon$-amine of lysine-14 in the large subunit of Rubisco. In addition, the present invention relates to a gene and a full-length cDNA clone for Rubisco LSMT, which was isolated utilizing polymerase chain reaction-based technology and conventional bacteriophage library screening. The present invention further relates to transgenic plants and methods of producing same which (1) have the Rubisco LSMT gene inserted into the DNA, and (2) have the Rubisco LSMT gene product deleted. Methods of using the gene to selectively deliver desired agents to a plant are also disclosed.

\section{Description of the Related Art}

Protein methylation is a widespread and common posttranslational modification catalyzed by several different protein methyltransferases (Paik et al, "Protein methylation," in Freedman et al (eds). The Enzymology of Posttranslational Modifications of Proteins, vol. 2, pp. 187-228. Academic Press, London (1985)). Proteins which contain trimethyllysyl residues include cytochrome c (Cessay et al, "The relationship between the trimethylation of lysine 77 and cytochrome c metabolism in Sacchanomyces cerevisiae," Int. J. Biochem. 26(5):721-734 (1994); Cessay et al, "Further investigations regarding the role of trimethyllysine for cytochrome c uptake into mitochondria," Int. J. Biochem. 23(7.8):761-768 (1991); DiMaria et al, "Cytochrome c specific methylase from wheat germ," Biochemistry 21:1036-1044 (1982); Farooqui et al, "Effect of Methylation on the Stability of Cytochrome c of Saccharomyces cerevisiae in vivo," J. Biol. Chem. 256(10):5041-5045 (1981); and Farooqui et al, "In vivo studies on yeast cytochrome $c$ methylation in relation to protein synthesis," J. Biol. Chem. 255(10):4468-4473 (1980)), calmodulin (Han et al. "Isolation and kinetic characterization of the calmodulin methyltransferase from sheep brain." Biochemistry 32:13974-13980 (1993); and Rowe et al, "Calmodulin N-methyltransferase," J. Biol. Chem. 261(15):7060-7069 (1986)), histone-H1 (Sarnow et al. "A histone H4-specific methyltransferase properties, specificity and effects on nucleosomal histones." Biochim. Biophys. Acta 655:349-358 (1981); and Tuck et al. "Two histone HI-specific protein-lysine $\mathrm{N}$-methyltransferases from Euglena gracilis," J. Biol. Chem. 260(11):7114-7121 (1985)), and ribosomal proteins (Chang et al. "Purification and properties of a ribosomal protein methylase from Escherichia coli Q13." Biochemistry 14(22):4994-4998 (1975); Lobet et al, "Partial purification and characterization of the specific protein-lysine N-methyltransferase of YL.32. a yeast ribosomal protein." Biochim. Biophy. Acta 997:224-231 (1989)). However, the biological function of 65 post-translational protein methylation in all but a few systems remains obscure. Trimethyllysine can serve as a meta-

\section{2}

bolic precursor to carnitine (Paik et al. "Carnitine biosynthesis via protein methylation," TIBS 2:159-162 (1977)), while carboxyl methylation of bacterial membrane proteins plays a major role in chemotaxis (Clarke. "Protein carboxyl 5 methyltransferases: Two distinct classes of enzymes," Ann. Rev. Biochem. 54:479-506 (1985)). Evidence suggests that methylation of Lys-115 in calmodulin affects certain activities including in vitro NAD kinase activation (Roberts et al. "Trimethyllysine and protein function." J. Biol. Chem. 261

10 (4):1491-1494 (1986)), and in vivo susceptibility to ubiquitination (Gregori et al. "Bacterially synthesized vertebrate calmodulin is a specific substrate for ubiquitination." $J$. Biol. Chem. 262(6) :2562-2567 (1987); and Gregori et al. "Specific recognition of calmodulin from Dictyostelium discoi-

15 deum by the ATP ubiquitin-dependent degradative pathway." J. Biol. Chem. 260(9):5232-5235 (1985); but see also Ziegenhagen et al, "Multiple ubiquitination of calmodulin results in one polyubiquitin chain linked to calmodulin," FEBS Lett. 271(1,2):71-75 (1990); and

20 Ziegenhagen et al, "Plant and fungus calmodulins are polyubiquitinated at a single site in a $\mathrm{Ca}^{2+}$-dependent manner," FEBS Lett. 273(1.2):253-256 (1990)). Conflicting reports (Farooqui et al, "Effect of Methylation on the Stability of Cytochrome c of Saccharomyces cerevisiae in vivo." J. Biol. 25 Chem. 256(10):5041-5045 (1981); Frost et al. "Cytochrome c methylation." Protein methylation, Ch. 4, pp. 59-76 (1990); and Frost et al. "Effect of enzymatic methylation of cytochrome $\mathrm{c}$ on its function and synthesis." Int. J. Biochem. 22(10):1069-1074 (1990); versus Cessay et al. "The rela30 tionship between the trimethylation of lysine 77 and cytochrome c metabolism in Saccharomyces cerevisiae," Int. J. Biochem. 26(5):721-734 (1994); Cessay et al. "Further investigations regarding the role of trimethyllysine for cytochrome c uptake into mitochondria." Int. J. Biochem. 23 (7. 35 8):761-768 (1991)) also implicate methylation of Lys -77 in cytochrome $c$ as having a role in protein stability, heme incorporation, and mitochondrial transport. A major limitation to elucidating the biological role of lysine methylation in eukaryotes has been the absence of a protein methylase III 4 gene. Hence, molecular studies of the physiological and biochemical function performed by methylation of protein bound lysyl residues have been restricted to site-directed mutational analysis of the methylation site in the target protein (Ceesay et al. "The relationship between the trim45 ethylation of lysine 77 and cytochrome c metabolism in Saccharomyces cerevisiae," Int. J. Biochem. 26(5):721-734 (1994); Cessay et al. "Further investigations regarding the role of trimethyllysine for cytochrome $c$ uptake into mitochondria." Int. J. Biochem. 23(7.8):761-768 (1991); 0 and Roberts et al, "Expression of a calmodulin methylation mutant affects the growth and development of transgenic tobacco plants." Proc. Nat. Acad. Sci. USA 89:8394-8398 (1992)). These studies have been inconclusive as to the exact biological role of methylation of the $\epsilon$-amine of protein bound lysyl residues.

Ribulose-1.5-bisphosphate carboxylase-oxygenase (Rubisco) catalyzes the reduction of atmospheric $\mathrm{CO}_{2}$ during photosynthesis. A great deal is known about the quaternary structure, catalytic mechanism. active site residues. in 60 vivo regulatory mechanisms. and gene expression for this abundant enzyme, see, for example. Andrews et al, "Rubisco: Structure. Mechanisms. and Prospects for Improvement." in Hatch et al (eds). The Biochemistry of Plants, vol. 10. pp. 131-218. Academic Press. New York (1987); Dean et al. "Structure. evolution. and regulation of rbcS genes in higher plants." Annu. Rev. Plant. Physiol. Plant Mol. Biol. 40:415-439 (1989); and Mullet. "Chloro- 


\section{$5,723.752$}

3

plast development and gene expression." Annu. Rev. Plant. Physiol. Plant Mol. Biol. 39:475-502 (1988). Higher plant Rubisco is a hexadecameric protein composed of eight chloroplast-encoded large subunits (referred to herein as "LS") and eight nuclear-encoded small subunits (referred to herein as "SS"). Synthesis of the LS is accompanied by post-translational processing of the $\mathrm{N}$-terminal domain (Houtz et al. "Post-translational modifications in the large subunit of ribulose bisphosphate carboxylase/oxygenase." Proc. Natl. Acad. Sci. USA 86:1855-1859 (1989); and Mulligan et al. "Reaction-intermediate analogue binding by ribulose bisphosphate carboxylase/oxygenase causes specific changes in proteolytic sensitivity: The amino-terminal residue of the large subunit is acetylated proline." Proc. Natl. Acad. Sci. USA 85:1513-1517 (1988)). The N-terminal Met-1 and Ser-2 are removed and Pro-3 acetylate. Additionally. the LS of Rubisco from tobacco, muskmelon. pea, and several other species is post-translationally modified by trimethylation of the $\epsilon$-amine of Lys-14 (Houtz et al "Posttranslational modifications in the amino-terminal region of the large subunit of ribulose-1,5-hisphosphate carboxylase/oxygenase from several plant species." "Plant Physiol. 98:1170-1174 (1992); Houtz et al. "Posttranslational modifications in the large subunit of ribulose bisphosphate carboxylase/oxygenase." Proc. Natl. Acad. Sci. USA 86:1855-1859 (1989)). The enzyme responsible for this latter modification is a highly specific chloroplastlocalized S-adenosylmethionine (AdoMet):protein (lys) €N-methyltransferase (protein methylase III. Rubisco LSMT, EC 2.1.1.43). Recently. Rubisco LSMT was affinity purified -8000 -fold from pea chloroplasts and identified as a monomeric protein with a molecular mass of $\sim 57 \mathrm{kDa}$ (Wang et al "Affinity Purification of Ribulose-1.5bisphosphate Carboxylase/Oxygenase Large Subunit eN-Methyltransferase," accepted by Protein Expression and Purification (1995)).

\section{OBJECTS AND SUMMARY OF THE INVENTION}

In view of the state of the art as previously described. there thus exists a need in the art for a better understanding of the biological function of post-translational protein methylation in higher plant systems. More specifically, a better understanding of the biological role of methylation of the $\epsilon$-amine of protein bound lysyl residues.

It is thus an object of the present invention to provide a Rubisco LSMT gene.

It is a further object of the present invention to provide the DNA and amino acid sequence for a Rubisco LSMT enzyme.

It is a still further object of the present invention to provide a full-length cDNA clone for Rubisco LSMT.

Another object of the present invention is to determine and selectively manipulate the biological role of lysine methylation in eukaryotes.

In a first aspect, the present invention relates to a Rubisco ISMT gene which is expressed in a higher plant and which encodes Rubisco LSMT. Rubisco LSMT catalyzes methylation of the $\epsilon$-amine of lysine-14 in the LS of Rubisco. A particularly preferred higher plant includes the pea.

In a second aspect. the present invention relates to the DNA and amino acid sequence for a Rubisco LSMT enzyme.

In a third aspect. the present invention relates to a recombinant vector including the Rubisco LSMT gene 65 described above. The vector is suitable for transforming higher plant seed crops.

\section{4}

In a fourth aspect, the present invention relates to an isolated or recombinantly expressed Rubisco LSMT enzyme encoded by the Rubisco LSMT gene described above.

In a fifth aspect, the present invention relates to a method 5 for introducing the Rubisco LSMT gene into a plant which does not possess said gene, which method comprises transforming a higher plant seed crop with the Rubisco LSMT gene vector described above such that the plant expresses the Rubisco LSMT enzyme encoded by the gene.

In a sixth aspect, the present invention relates to a method for selectively eliminating a plant which comprises the Rubisco LSMT gene by deleting the gene product, or eliminating the action of the gene product. from the plant. Without the Rubisco LSMT gene product or the action of the gene product, the plant would be unable to catalyze net $\mathrm{CO}_{2}$ fixation during photosynthesis and would thus die.

In a seventh aspect. the present invention relates to a method for introducing agents to a plant cell which agents will selectively increase or decrease activity of Rubisco.

In a further aspect. the present invention relates to a 20 recombinant or transgenic plant transformed with the Rubisco LSMT gene described above.

\section{BRIFF DESCRIPTION OF THE DRAWINGS}

FIGS. 1A-1B show a reverse phase-HPLC of peptic 25 polypeptides from Rubisco LSMT. FIG. $1 a$ shows the control of peptic digestion of Immobilon-CD membrane without Rubisco LSMT. FIG. $1 b$ shows the peptic digestion of affinity-purified Rubisco LSMT $(-30 \mu \mathrm{g})$ electroblotted to Immobilon-CD membrane as described in the Examples. The asterisks identify peaks with $A_{214}$ absorbance which were collected and submitted for amino acid sequence analyses.

FIGS. 2A, 2B and 2C (SEQ. ID NO. 41) illustrate the nucleotide and predicted amino acid sequence of pea rbcMT cDNA. Nucleotide position is marked on the right. The start

35 and stop codons are underlined and segments corresponding to peptic fragments are marked by lines above the aminoacid sequence. The position of amino acids encoded by the PCR-derived partial cDNA is blocked.

FIG. 3 shows a Southern blot analysis of the rbcMT gene 40 in pea. Ten $\mu \mathrm{g}$ of genomic DNA from pea was digested with EcoR I. Hind III. or Dra I, and electrophoresed on an $0.8 \%$ agarose gel. The blot was probed with a 1775 bp rbcMT cDNA of pea. Approximate sizes in kbp are indicated to the left. Blots were exposed to $x$-ray film for 48 hours.

45 FIG. 4 illustrates organ-specific accumulation of rbcMT mRNA. Messenger-RNA was isolated from roots. stems. and leaves of 10 day old chamber-grown pea. Northern blots were loaded on an equal RNA basis and were probed with radiolabeled antisense RNA to rbcS, rbcl or rbcMT. North50 ern blots of rbcS, rbcL and rbcMT mRNA were exposed to $x$-ray film for 2 hours, 1 hour. and 36 hours, respectively.

In FIG. 5. light-dependent accumulation of rbcMT mRNA in etiolated pea is shown. Peas were germinated in a dark chamber in a light-tight room. After 8 days. etiolated seed55 lings were either harvested (treatment 1) or transferred to the light for 24 hours (treatment 2) or 72 hours (treatment 3 ). Control seedlings were germinated in the light and harvested after 8 days (treatment 4 ). RNA was isolated from leaf tissue from each treatment and Northern analyses were conducted.

60 Northern blots of rbcS. rbcL. and rbcMT were exposed to $\mathrm{x}$-ray film for 1 hour. 1 hour. and 36 hours, respectively.

\section{DETAIIED DESCRIPTION OF THE INVENTION}

The present invention relates to a Rubisco LSMT gene, its DNA and amino acid sequence encoding therefor, and a cDNA clone thereof. 


\section{5}

In the present application, naturally occurring amino acid residues in peptides are abbreviated as recommended by the IUPAC OIUB Biochemical Nomenclature Commission as follows: Phenylalanine is Phe or F; Leucine is Leu or L; Isoleucine is Ile or $\mathrm{I}$; Methionine is Met or M; Norleucine is Nle; Valine is Val or V; Serine is Ser or S; Proline is Pro or $\mathrm{P}$; Threonine is Thr or T; Alanine is Ala or A; Tyrosine is Tyr of $\mathrm{Y}$; Histidine is His or $\mathrm{H}$; Glutamine is Gln or Q; Asparagine is Asn or N; Lysine is Lys or $\mathrm{K}$; Aspartic Acid is Asp or D; Glutamic Acid is Glu or E; Cysteine is Cys or C; Tryptophan is Trp or W; Arginine is Arg or R; Glycine is Gly or $G$, and $X$ is any amino acid.

Synthetic or non-naturally occurring amino acids refer to amino acids which do not naturally occur in vivo but which. nevertheless. can be incorporated into the peptide structures described herein. Preferred synthetic amino acids are the D-amino acids of naturally occurring L-amino acids as well as non-naturally occurring $D$ and $L$ amino acids represented by the formula $\mathrm{H}_{2} \mathrm{NCHR}{ }^{1} \mathrm{COOH}$, wherein $\mathrm{R}^{1}$ is: (1) a lower alkyl group; (2) a cycloalkyl group of from 3 to 7 carbon atoms; (3) a heterocycle of from 3 to 7 carbon atoms and 1 to 2 heteroatoms selected from the group consisting of oxygen. sulfur, and nitrogen; (4) an aromatic or arylalkyl residue of from 6 to 15 carbon atoms optionally having from 1 to 3 substituents on the aromatic nucleus selected from the group consisting of hydroxyl, lower alkoxy, amino. and carboxyl; (5) alkylene-Y where alkylene is an alkylene group of from 1 to 7 carbon atoms and $Y$ is selected from the group consisting of hydroxy, amino. cycloalkyl of from 3 to 7 carbon atoms. heterocyclic of from 3 to 7 carbon atoms and 1 to 2 heteroatoms selected from the group consisting of oxygen, sulfur and nitrogen, and $-C(O) R^{2}$ where $R^{2}$ is selected from the group consisting of hydrogen. lower alkyl. lower alkoxy, and -NR $R^{4}$ where $R^{3}$ and $R^{4}$ are independently selected from the group consisting of hydrogen and lower alkyl; (6) alkylene-S $(O)_{n} R^{5}$ where $n$ is 1 or 2 , and $R^{5}$ is a lower alkyl or lower alkylene.

Particularly preferred synthetic amino acids include, by way of example. the D-amino acids of naturally occurring L-amino acids. L-1-napthylalanine, L-2-naphthylalanine, L-cyclohexylalanine, L-2-amino isobutyric acid, the sulfoxide and sulfone derivatives of methionine, and the lower alkoxy derivatives of methionine.

"Peptide mimetics" are also encompassed by the present invention and include peptides having one or more of the following modifications:

peptides wherein one or more of the peptidyl $[-\mathrm{C}(\mathrm{O})$ $\mathrm{NH}-\mathrm{l}$ linkages (bonds) have been replaced by a nonpeptidyl linkage such as carbamate linkage $[-O C(O) N$ $<$ ], phosphonate linkage. amidate linkage, sulfonamide linkage, and secondary amine linkage or with an alkylated peptidyl linkage $\left[C(O) N^{6}\right.$ - where $R^{6}$ is a lower alkyl],

peptides wherein the $\mathrm{N}$-terminus is derivatized to a $-\mathrm{NR}^{7} \mathrm{R}^{8}$ group, to a $-\mathrm{NC}(\mathrm{O}) \mathrm{R}^{7}$ group where $\mathrm{R}^{7}$ and $R^{8}$ are independently selected from hydrogen and lower alkyls with the proviso that $R^{7}$ and $R^{8}$ are both not hydrogen, to a succinimide group. to a benzyloxycarbonyl-NH- $(\mathrm{CBZ}-\mathrm{NH}-)$ group, to a benzyloxycarbonyl-NH- group having from 1 to 3 substituents on the phenyl ring selected from the group consisting of lower alkyl. lower alkoxy. chloro. and bromo.

peptides wherein the $\mathrm{C}$ terminus is derivatized to $>\mathrm{C}(\mathrm{O})$ 65 $R^{9}$ where $R^{9}$ is selected from the group consisting of hydrogen. lower alkyl. lower alkoxy, and $N^{10} R^{11}$
6

where $R$ and $R^{11}$ are independently selected from the group consisting of hydrogen and lower alkyl.

Although the present invention is described with respect to peas, it will be appreciated that the techniques employed herein are applicable to other photosynthesizing plants, e.g., legumes, soybeans, solanaceae (tomato, potato, tobacco, pepper) and cucurbitaceae (cucumbers. melons. gourds). The protein methylase III of other photosynthesizing plants would be expected to exhibit homologous amino acid sequences to those described herein. As described herein. certain aspects of the present invention are applicable to plants not having the Rubisco LSMT gene, e.g.. spinach. wheat, corn, lower plants such as algae, monocots (cereals) and the like.

Ribulose-1,5-hisphosphate carboxylase/oxygenase 5 (Rubisco) large subunit (LS) $\mathrm{eN}$-methyltransferase (referred to herein as "Rubisco LSMT") catalyzes methylation of the $\epsilon$-amine of lysine-14 in the LS of Rubisco. Rubisco is the world's most abundant protein. and serves as the only significant link between the inorganic and organic carbon pools in the Earth's biosphere by catalyzing the reduction of atmospheric carbon dioxide to carbohydrates during photosynthesis. Perturbations of Rubisco activity translate directly into similar changes in plant growth and yield. Thus, there is significant interest in the art in the potential manipulation and control of Rubisco activity through genetic engineering.

However, the complexity and multimeric nature of Rubisco have proven to be substantial obstacles to achieving this goal, which have not yet been overcome. Rubisco LSMT provides an opportunity for the selective manipulation of Rubisco activity through changes in the structure and stability of the N-terminal region in the LS, an area known to be essential for catalytic activity. Rubisco LSMT is a highly specific enzyme which is found to interact only with Rubisco and does not interact with any other protein in the plant cell. Since Rubisco catalyzes the reduction of atmo5 spheric $\mathrm{CO}_{2}$ during photosynthesis, Rubisco and Rubisco LSMT are critical to the plant cell for viability. Furthermore. the exceptionally tight and specific nature of the interaction between Rubisco LSMT and des(methyl) forms of Rubisco creates the possibility for the development of novel synthetic polypeptide herbicides, whose target is the in vivo interaction between Rubisco LSMT and Rubisco. whose specificity crosses a group of plant species related only by the presence of Rubisco LSMT, and whose target protein has no homologue in the entire animal kingdom. Finally, this same 45 affinity of Rubisco LSMT for des(methyl) forms of Rubisco also creates the possibility for the site and protein specific delivery of compounds into the chloroplast and to Rubisco. for the potential manipulation of Rubisco activity and/or stability.

With limited internal amino acid sequence information obtained from high performance liquid chromatography (HPLC)-purified peptic polypeptides from Rubisco LSMT, a full-length cDNA clone was isolated by the present inventor utilizing polymerase chain reaction (PCR)-based technology 55 and conventional bacteriophage library screening. PCR techniques are disclosed. for example, in Klein et al. "Cloning and Developmental Expression of the SucrosePhosphate-Synthase Gene From Spinach." Planta 190:498-510 (1993); in Ampli-Taq PCR kit by Perkin 60 Elmer-Cetus. Emeryville. Calif.); and in the manufacturer's instruction manual. Bacteriophage library screening is described. for example. in Gantt et al, "Transfer of rp122 to the Nucleus Greatly Preceded its loss from the Chloroplast and Involved the Gain of an Intron." EMBO J 10:3073-3078 (1991), and in the information provided by the manufacturer of the screening membrane (Stratagene. La Jolla, Calif.). 
7

The 1802-base-pair cDNA of Rubisco LSMT encodes a 489-amino acid polypeptide with a predicted molecular mass of $-55 \mathrm{kDa}$. To the knowledge of the present inventor. this is the first reported DNA and amino acid sequence for a protein methylase III enzyme. A derived N-terminal amino acid sequence of the polypeptide with features common to chloroplast transit peptides was identified. The deduced sequence of Rubisco LSMT did not exhibit regions of significant homology with other protein methyltransferases known in the art. e.g. D-aspartyl/L-isoaspartyl protein methyltransferase (Kagan et al, "Widespread occurrence of three sequence motifs in diverse $S$-adenosylmethioninedependent methyltransferases suggests a common structure for these enzymes." Arch. Biochem. Biophy. 310(2):417-427 (1994)). Widespread occurrence of three sequence motifs in diverse $\mathrm{S}$-adenosylmethionine dependent methyltransferases suggest a common structure for these enzymes. Southern blot analysis of pea genomic DNA indicated a low gene copy number of Rubisco LSMT in pea. A "low gene copy number" indicates that Rubisco LSMT may be encoded by a single gene. Northern analysis revealed a single mRNA species of about $1.8 \mathrm{~kb}$ encoding for Rubisco LSMT which was predominately localized in leaf tissue. Illumination of etiolated pea seedlings showed that the accumulation of Rubisco LSMT mRNA is light-dependent. Maximum accumulation of Rubisco LSMT transcripts occurred during the initial phase of light-induced leaf development which preceded the maximum accumulation of rbeS and rbcL mRNA. Transcript levels of Rubisco LSMT in mature light-grown tissue were similar to transcript levels in 30 etiolated tissues indicating that the light-dependent accumulation of Rubisco LSMT mRNA is transient.

A cDNA of the Rubisco LSMT gene from pea was isolated and studies of Rubisco LSMT gene expression initiated. Utilizing amino acid sequence information derived from purified peptic polypeptide fragments from proteolyzed Rubisco LSMT, a full-length cDNA of Rubisco LSMT was obtained. The cDNA of Rubisco LSMT, IbcMT, was used to examine organ-specific and developmental parameters affecting rbcMT gene expression. The expression of two well characterized gene families, rbaS (SS of Rubisco) and rbcL (LS of Rubisco), were also examined to determine if rbcMT expression is coregulated with that of the Rubisco subunit genes, particularly the LS.

The present specification details the purification of peptic fragments from pea Rubisco LSMT and a PCR-based cloning strategy for isolating a full-length cDNA. A similar strategy was previously utilized to obtain a full-length cDNA of sucrose-phosphate synthase from spinach (Klein et al, "Cloning and developmental expression of the sucrosephosphate-synthase gene from spinach." Planta. 190:498-510 (1993)). The low abundance of Rubisco LSMT in pea leaves $(-0.01 \%)$ prompted the use of PCR, since it would be more difficult to obtain enough protein to ensure the production of an antibody with high-titer and specificity with which to screen a library. Further, the protein sequence information obtained from peptic fragments permitted the confirmation of clones encoding for Rubisco LSMT. Hence. a molecular probe of the pea rbcMT gene was rapidly obtained thereby permitting identification of protein and nucleotide sequence, and characterization of rbcMT gene expression.

To date. the deduced amino-acid sequence of Rubisco LSMT represents the first reported example of a protein eN-methyltransferase. Thus, it is now possible to extend the comparison of known enzyme sequences to include this class of methyltransferases. Interestingly, the deduced

\section{8}

amino acid sequence of Rubisco LSMT does not possess any of the three sequence motifs proposed by Kagan and Clarke (Kagan et al. "Widespread occurrence of three sequence motifs in diverse S-adenosylmethionine-dependent methyl5 transferases suggests a common structure for these enzymes," Arch. Biochem. Biophy. 310(2):417-427 (1994)) for methyltransferases. However, knowledge of methyltransferase sequences is still fragmentary and no sequences are yet available for protein arginine, histidine, or $10 \mathrm{~N}$-terminal amino methyltransferases. As noted by Kagan and Clarke, methyltransferases whose sequences are available represent less than one-third of these enzymes and a number of other methyltransferases apparently do not possess the proposed motifs or any additional elements of 15 sequence similarity. Furthermore, several lines of evidence suggest that Rubisco LSMT exclusively methylates the large subunit of Rubisco (Houtz et al. "Posttranslational modifications in the amino-terminal region of the large subunit of ribulose-1,5-bisphosphate carboxylase/oxygenase from sev-

20 eral plant species." Plant Physiol. 98:1170-1174 (1992); and Houtz et al, "Partial purification and characterization of ribulose-1.5-bisphosphate carboxylase/oxygenase large subunit $\in \mathrm{N}$-methyltransferase." Plant Physiol. 97:913-920 (1991)). This high level of specificity may in part explain the 25 lack of overall homology with other methyltransferases. Hence, sequence determination of other yet-to-bediscovered protein(lys) $\in \mathrm{N}$-methyltransferases may be necessary to identify conserved, functionally essential regions in this class of enzyme.

30 Several lines of evidence indicate that there is a low copy number of the rbcMT gene in pea. Genomic Southern blot analysis revealed simple hybridization patterns. DNA sequence information of several cDNA clones revealed an invariant nucleotide sequence in the coding and noncoding 35 regions. Although these observations do not preclude the existence of multiple structural genes encoding Rubisco LSMT, they are consistent with a low- or even single-copy gene hypothesis.

Many plant genes are expressed in a highly regulated 40 manner. Gene products may be present only in certain cell types, at specific stages of development or only following the application of distinct environmental stimuli (Kuhlemeier et al. "Regulation of gene expression in higher plants," Annu. Rev. Plant Physiol. 38:221-257 (1987)). In 45 addition. the expression of nuclear genes encoding plasmid proteins is often coordinated with the expression of plastidencoded protein subunits (Rapp et al, "Chloroplast transcription is required to express the nuclear genes rocS and cab." Plant Mol. Biol. 17:813-823 (1991)). The present specifi50 cation shows that rbcMT gene expression is regulated in an organ-specific manner at the level of transcription or mRNA stability. The organ-specific expression of rbcMT paralleled that of rbcS and rbcL being predominately localized to photosynthetic leaf tissue. Examination of transcript levels 55 during the light-induced development of etiolated pea leaves indicated that accumulation of mRNA encoding for rbcS. rbcL, and rbcMT is light-dependent. However, the activation of rbcMT expression preceded the maximum accumulation of mRNA encoding for either of the Rubisco subunits. 60 Maximum transcript levels for rbcMT were obtained in the first 24 hours of illumination. which corresponded with the initial. light-dependent phase of rbcS and rbcL transcript accumulation. Interestingly, the kinetics of Rubisco activase mRNA accumulation during the greening of etiolated barley 65 was similar to that reported here for rbcMT mRNA (Zielinski et al. "Coordinate expression of rubisco activase and rubisco during barley leaf cell development." Plant 
9

Physiol. 90:516-521 (1989)). The present inventor also observed that in continuously illuminated pea leaves rbcMT transcript levels were equal to the levels observed in darkgrown leaves (FIG. 5), while the activity of Rubisco LSMT was nearly 3-fold higher. Since the relative amounts of rbcMT transcripts increased dramatically during the initial phase of light-induced development of etiolated pea leaves and then declined to a level equal to those observed in the dark. changes in the level of Rubisco LSMT protein may be controlled by the level of rbcMT transcripts.

Finally, while a number of $\in \mathrm{N}$-methylated lysyl residues in several proteins have been described, no unifying hypothesis with regards to the functional significance of methylated lysyl residues has been discovered. Molecular studies have approached this topic by engineering amino acid substitutions at the position of the methylation lysyl residue in calmodulin (Roberts et al, "Expression of a calmodulin methylation mutant affects the growth and development of transgenic tobacco plants," Proc. Nat. Acad. Sci. USA 89:8394-8398 (1992)) and cytochrome c (Cessay et al. "The relationship between the trimethylation of lysine 77 and cytochrome c metabolism in Saccharomyces cerevisiae," Int. J. Biochem. 26(5):721-734 (1994); and Cessay et al. "Further investigations regarding the role of trimethyllysine for cytochrome c uptake into mitochondria," Int. J. Biochem. 23(7.8):761-768 (1991)), followed by expression of these mutant proteins in transformed tobacco plants and yeast cells. respectively. While the mutated calmodulin and cytochrome $\mathrm{c}$ proteins were incapable of acting as substrates for methylation, these studies were inconclusive as to a clear 30 role for site-specific methylation of the target lysyl residues by the calmodulin or cytochrome $c$ protein specific $\in \mathrm{N}$-methyltransferases.

The present invention also relates to a method for introducing the Rubisco LSMT gene into a plant which does not possess said gene, such as Arabidopsis thaliana. The methods employed for transforming the plants are generally known in the art. For example. the transformation method described in Bechtold et al. Planta Agrobacterium Mediated Gene Transfer By Infiltration of Adult Arabidopsis Thaliana 40 Plants, C.R. Acad. Sci., Paris 316:1194-1199 (1993) and Valvekens et al. "Agrobacterium tumefaciens-mediated transformation of Arabidopsis thaliana root explants by using kanamycin selection," Proc. Natl. Acad. Sci. USA $85: 5536-5540$ (1988), may be used in the method of the present invention. More specifically, the method contemplated herein comprises transforming a plant with the Rubisco LSMT gene vector described above such that the plant expresses the Rubisco LSMT enzyme encoded by the gene. These methods produce transgenic plants, which will have Rubisco LSMT activity and Lys-14 methylation in the LS of Rubisco.

Further, the present invention provides a method for deleting the Rubisco LSMT gene product or the action of the gene product in a photosynthesizing plant which has the ss Rubisco LSMT gene. Knowing the DNA sequence of the Rubisco LSMT gene, transgenic plants can be constructed expressing antisense RNA to Rubisco LSMT which results in the down-regulation of the Rubisco LSMT gene product. by methods as set forth for example, in Eguchi et al. "Antisense RNA." Annu. Rev. Biochem. 60:631-652 (1991). Since the Rubisco LSMT enzyme is essential for Rubisco activity, the deletion of the enzyme would be expected to be lethal to the plant since it would be unable to catalyze net $\mathrm{CO}_{2}$ fixation during photosynthesis. This method, and varia- 65 tions of this method. could thus be used as a herbicide to selectively eliminate photosynthesizing plants.

\section{0}

Due to the high specificity of Rubisco LSMT for Rubisco. knowledge of the sequence for the Rubisco LSMT gene can be used to introduce agents to a plant cell which agents will selectively increase or decrease the activity of Rubisco.

5 Additionally, in this regard, a recombinant vector comprising the sequence of the Rubisco LSMT gene responsible for the tight interaction of Rubisco LSMT with Rubisco could be constructed. Additional agents which enhance or reduce the activity of Rubisco, for example, CA1P 10 (carboxyarabinitol-1-phosphate), CABP (carboxyarabinitol bisphosphate). carbamates and divalent metal cations, are then conjugated to the vector. The vector is then inserted into the plant cell by methods known in the art. The agents will then be delivered to Rubisco as a result of the high speci15 ficity and strong interaction of Rubisco LSMT and Rubisco. These agents may be synthetically derived polypeptides that are direct representations of the sequence of amino acids responsible for the interaction of Rubisco LSMT with Rubisco. These synthetic polypeptides would delete Rubisco 20 LSMT activity and result in plant death in the aforementioned manner.

Moreover, the particular sequence disclosed herein for the pea Rubisco LSMT gene may be used to determine the particular sequence in other photosynthesizing plants. The 25 sequence of the gene may be used as a probe to screen cDNA or genomic DNA libraries from other plants and. due to the expected homology between the gene sequences in the various plant species, the particular sequence for the Rubisco LSMT gene in other species may then be found.

30 In a further aspect. the present invention relates to a recombinant or transgenic plant transformed with the Rubisco LSMT gene described above.

Having now generally described this invention, the same will be better understood by reference to certain specific examples, which are included herein for purposes of illustration only and are not intended to be limiting of the invention or any embodiment thereof, unless so specified.

\section{EXAMPLES}

Example 1

\section{Plant Growth}

Controlled environment-cultured peas (Pisum sativum) were germinated and maintained in environmental chambers as described in Wang et al, Protein Expression and Purifcation. For developmental studies, seeds were either germinated at $23^{\circ} \mathrm{C}$. in a dark chamber located in a light-tight room or were grown in an illuminated chamber with a light intensity of $300 \mu \mathrm{mol} \cdot \mathrm{m}_{-2} \cdot \mathrm{s}^{-1}$ (incandescent plus fluorescent). After 8 days of growth in complete darkness. pea seedlings were either harvested into liquid nitrogen or were transferred to an illuminated chamber for a predetermined period prior to harvest. 55

\section{Purification and assay of Rubisco LSMT}

Rubisco LSMT was affinity purified utilizing immobilized spinach Rubisco as describe in Wang et al, cited supra. 60 Briefly. purified spinach Rubisco (McCurry et al. "Ribulose1.5-bisphosphate carboxylase/oxygenase from spinach. tomato or tobacco leaves." Methods in Enzymology 90(82) :515-521 (1982)) was immobilized to PVDF membranes (Millipore Corp.. Bedford, Mass. USA. $60 \mathrm{mg}$ Rubisco/450 $65 \mathrm{~cm}^{2}$ ) which were then incubated for $4 \mathrm{~h}$ at $4^{\circ} \mathrm{C}$. with pea chloroplast lysates $\left(20 \mathrm{ml}\right.$ at $20 \mathrm{mg} / \mathrm{ml}$ protein per $450 \mathrm{~cm}^{2}$ membrane). After incubation. the PVDF membranes were 
11

washed with $50 \mathrm{mM}$ TRIS-HCl (pH 8.2), $5 \mathrm{mM} \mathrm{MgCl}_{2}$. 1 mM EDTA. $0.4 \mathrm{M} \mathrm{NaCl}$ and subsequently eluted with $20 \mathrm{ml}$ of $50 \mathrm{mM}$ TRIS-HCl (pH 8.2), $5 \mathrm{mM} \mathrm{MgCl}, 200 \mu \mathrm{M}$ AdoMet and $50 \mu \mathrm{g} / \mathrm{ml} \beta$-lactoglobulin per $450 \mathrm{~cm}^{2} \mathrm{mem}-$ brane. The eluent was concentrated by centrifugal ultrafiltration to a final volume of $-50 \mu \mathrm{l}$ and used as a source for purified Rubisco LSMT. The yield from a single PVDF membrane containing immobilized spinach Rubisco was typically $7-10 \mu \mathrm{g}$ of purified Rubisco LSMT. Assays of Rubisco LSMT activity were as previously described (Houtz et al. "Partial purification and characterization of ribulose1.5-bisphosphate carboxylase/oxygenase large subunit eN-methyltransferase." Plant Physiol. $97: 913$-920 (1991)).

\section{Example 3}

Peptide profiles and sequence analysis

To separate affinity-purified Rubisco LSMT from the $\beta$-lactoglobulin carrier protein. Rubisco LSMT was resolved by SDS-PAGE (10\% acrylamide) prior to electrophoretic transfer to Immobilon-CD membranes (Millipore Corp. Bedford, Mass. USA). Conditions for the electrophoretic transfer, visualization and subsequent in vitro enzymatic cleavage of Rubisco LSMT with pepsin were as described. for example, by Paik et al. "Protein methylation," in Freedman et al (eds), The Enzymology of Posttranslational Modifications of Proteins, vol. 2, pp. 187-228, Academic Press. London (1985). Peptic peptides released from Rubisco LSMT were isolated by reverse phase-HPLC using conditions described in Patterson et al. "High-yield recovery of electroblotted proteins and cleavage fragments from a cationic polyvinylidene fluoride-based membrane," Anal. Biochem. 202:193-203 (1992), with an Aquapore RP-300 7

\section{2}

micron particle size octyl reverse phase column (2.1 mm $\times 220 \mathrm{~mm}$. Applied Biosystems, San Jose, Calif. USA). Peptic peptides were manually collected based on absorbance at $214 \mathrm{~nm}$ and samples reduced in volume to $\sim 50 \mu \mathrm{l}$ 5 under vacuum. Amino-acid sequence analyses were performed by the Macromolecular Structure Analysis Facility at the University of Kentucky, Lexington. using an Applied Biosystems 477A automated sequencer. For additional confirmation of amino acid sequence data, a duplicate sample of o Rubisco LSMT was purified, proteolyzed, and peptic polypeptide fragments submitted for amino acid sequence analyses.

15

Example 4

Synthesis of first-strand cDNA and polymerase chain reaction amplification

Pools of oligonucleotide primers encoding portions of 20 two LSMT peptic peptides, P14 and P18, were synthesized with the number of different species (degeneracies) in each pool minimized as previously described (Klein et al. "Cloning and developmental expression of the sucrose-phosphatesynthase gene from spinach." Planta. 190:498-510 (1993)). First strand cDNA synthesis and polymerase chain reaction (PCR) conditions were as described, for example. in Klein et al, "Cloning and developmental expression of the sucrosephosphate-synthase gene from spinach." Planta. 190:498-510 (1993), except $5 \mu$ l of first strand cDNA was used as PCR-template and the PCR-annealing temperature was reduced to $48^{\circ} \mathrm{C}$. The appropriate sense and antisense PCR-primers directed against LSMT peptides, P14 and P18. are shown in Table 1, as shown below.

TABLE 1

Degenerate PCR primer pools designed acconding to amino-acid sequence of Rubisco LSMT peptides P14 and P18. Underlined nucleotides represent degeneracy nearest 3' termimus at which pools or primers differ.

PEPTIDE P14

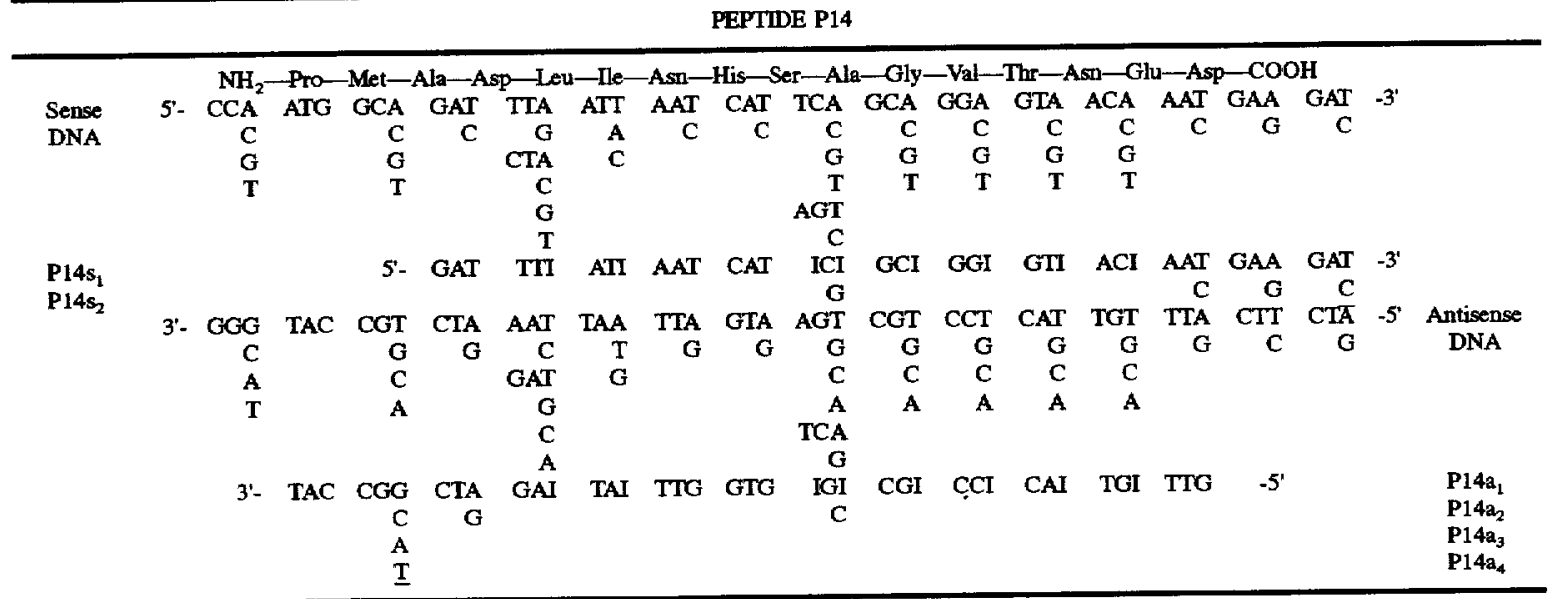

PEPTIDE P18

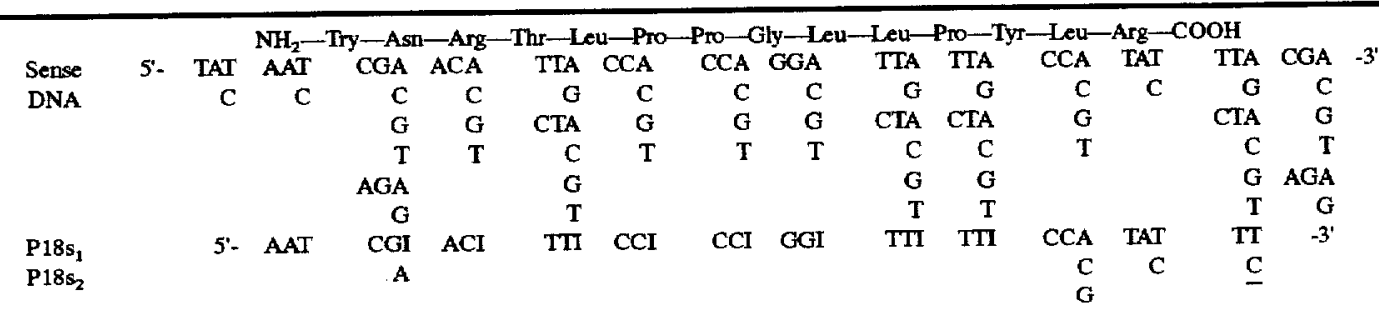


TABLE 1-continued

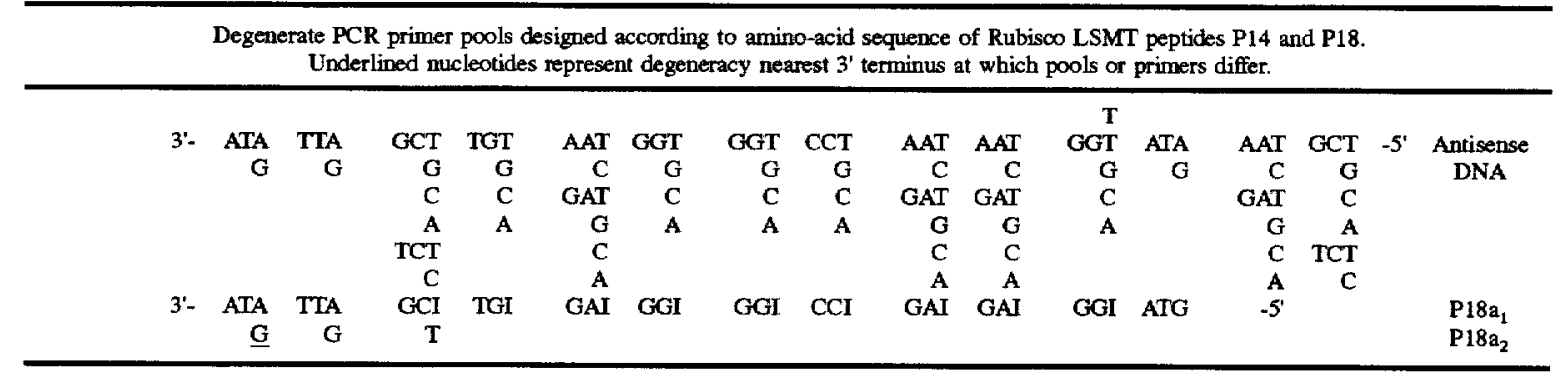

Following amplification, the PCR product was purified and blunt-end ligated into the SK plasmid (Stratagene, La Jolla, Calif. USA) and sequenced as described. for example, in Klein et al. "Photoaffinity labeling of mature and precursor forms of the small subunit of ribulose-1.5-bisphosphate carboxylase/oxygenase after expression in Escherichia coli," Plant Physiol. 98:546-553 (1992).

\section{Example 5}

\section{Screening of a pea cDNA library}

To obtain a full-length cDNA of pea LSMT, a pea $\lambda \mathrm{gt} 10$ cDNA library (Gantt et al. "Transfer of $\mathrm{mp} 122$ to the nucleus greatly preceded its loss from the chloroplast and involved the gain of an intron." EMBO J 10:3073-3078 (1991)) was screened with the Rubisco LSMT-PCR product. Approximately $5 \times 10^{4}$ primary plaques were screened with a randomly labeled 360-bp PCR product of Rubisco LSMT under recommended conditions (Stratagene, La Jolla, Calif. USA). After four rounds of plaque purification, three potential positive plaques were identified. Following amplification and purification of bacteriophage DNA. Rubisco LSMT cDNAs were subcloned into SK plasmid and the complete sequence of all three clones (approximately 1600 to $1775 \mathrm{bp}$ in length) was obtained.

The technique of PCR-RACE (Rapid Amplification of cDNA Ends) was used to obtain a portion of the 5'-region of LSMT essentially as described by the manufacturer (GIBCO-BRL. Gaithersburg, Md. USA) except 100-ng of poly(A) mRNA was substituted for total RNA. The genespecific (antisense) primer used to prime synthesis of firststrand LSMT cDNA was 5'-CCAAAAGAAGTCATCCAGCGTCAC (SEQ. ID NO. 41. position $700-667 \mathrm{bp}$ ). Amplification by PCR used the Anchor primer (supplied by GIBCO-BRL) and a second antisense LSMT-specific primer (5'CAUCAUCAUCAUCCTGTGGCAGAATACCAAAATAGT) which annealed to an internal, nested site within the LSMT cDNA (SEQ. ID NO. 41, position $515-492$ bp). The inclusion of the $(\mathrm{CAU})_{4}$ repeat sequence at the $5^{\prime}$ terminus permitted a uracil DNA glycosylase (UDG) cloning strategy of the PCR-RACE product. PCR amplification conditions were as above except for an annealing temperature of $55^{\circ} \mathrm{C}$. and an extension time of 40 seconds.

\section{Example 6}

Northern blot analyses

Polyadenylated mRNA ( $0.5 \mu \mathrm{g}$ per lane) or total RNA (2 $\mu \mathrm{g}$ per lane) was loaded on formaldehyde gels (Sambrook et al. Molecular cloning: A laboratory manual. Cold Spring Harbor Laboratory Press. Cold Spring Harbor. N.Y. (1989)) and transferred to GeneScreen nylon membranes (DuPont-
15 EN. Wilmington. De1. USA). Conditions for prehybridization and hybridization with radiolabeled antisense-RNA probes were as described in Klein et al. "Cloning and developmental expression of the sucrose-phosphatesynthase gene from spinach." Planta. 190:498-510 (1993). The northern probe for rbcS was as also described in Klein et al, supra; and Klein et al, "Photoaffinity labeling of mature and precursor forms of the small subunit of ribulose-1.5bisphosphate carboxylase/oxygenase after expression in 25 Escherichia coli," Plant Physiol. 98:546-553 (1992)); the probe for rbcL was as described in Klein et al. "Lightinduced Transcription of Chloroplast Genes." J. Biol. Chem. 265(4):1895-1902 (1990)). The probe for rbcMT was a 1750-base antisense RNA from a portion of the open reading 30 frame and 3 -untranslated region of pea.

\section{Example 7}

Genomic Southern blot analyses

Nuclear DNA was isolated from nuclei as described in 5 Bedbrook, "A plant nuclear DNA preparation procedure." Plant Mol. Biol. Newslett. 2:24 (1981). Ten $\mu \mathrm{g}$ of high molecular weight DNA was digested to completion with EcoR I. Hind III. and Dra I (50 units each). Following digestion, DNA was ethanol precipitated, electrophoresed on $0.8 \%$ agarose gels and transferred to Nytran nylon membranes using an alkaline transfer solution as described (Turboblotter instruction manual, Schleicher and Schuell, Keene, N.H. USA). Blots were prehybridized and hybridized at $42^{\circ} \mathrm{C}$. in the presence of $50 \%$ formamide and $10 \%$ 45 dextran sulfate. The probe was a random primer-labeled 1775 bp cDNA of pea LSMT (encompassing the open reading frame and entire 3 '-untranslated region).

\section{Example 8}

Computer alignment of the amino acid sequences was performed using the FastDB program (Intelligenetics Inc. Mountain View, Calif. USA). Autoradiograms were scanned with an image acquisition densitometer (Biolmage. 55 Milligen/Biosearch. Ann Arbor, Mich. USA) to determine the relative intensity of mRNA signal and quantified on the basis of whole-band analysis.

In accordance with the present invention, rubisco LSMT has thus been purified $\sim 8000$-fold by a novel affinity puri60 fication technique from pea chloroplasts as described in Wang et al, Protein Expression and Purification. After affinity-purification of Rubisco LSMT, SDS-PAGE analysis showed a single polypeptide with an apparent molecular mass of $\sim 57 \mathrm{kDa}$. Direct Edman degradative sequencing 65 attempts followed by amino acid analyses after $\mathrm{HCl}$ hydrolysis of electroblotted affinity-purified Rubisco LSMT revealed that the $\mathrm{N}$-terminus was blocked. Thus, subsequent 
15

efforts were directed towards the acquisition of internal amino acid sequence as a starting point for isolating a cDNA of pea Rubisco LSMT. Reverse phase-HPLC isolation of peptic fragments from Rubisco LSMT resulted in the identification of several reliable amino acid sequences (FIG. 1 , asterisks). One polypeptide peak. however. was heterogeneous and consisted of at least three subsequences which were identifiable based on differences in the relative amino acid yields after each cycle of sequencing.

\section{Example 9}

The partial amino-acid sequence of Rubisco LSMT enabled the inventor to develop a molecular probe for the Rubisco LSMT gene (rbcMT) using PCR. Pools of deoxyinosinecontaining primers encoding part of two peptic peptides, P14 and P18, were synthesized with the number of species in each pool minimized, as shown in Table 1, supra. Using random-hexamer-primed first strand cDNA as a template, the combination of primer pools P14-2s with P18-1a or P18-2a directed the synthesis of a single 360-bp PCR product. No other primer combinations yielded a detectable PCR product.

The fact that either antisense primer P18-1a or P18-2a (which differ by a single nucleotide near the 3 ' terminus) directed the synthesis of a PCR product reflects the relative tolerance of the PCR system for base-pair mismatches near the $3^{\prime}$ terminus of the primer. The identity of the amplification product as a partial cDNA of rbcMT was confirmed by comparison of the deduced amino-acid sequence of the PCR product with additional peptic fragments from purified pea Rubisco LSMT protein (see FIG. 2).

The PCR-amplified fragment of rbcMT was used to screen a $\lambda$ gt10 pea cDNA library (Gantt et al. "Transfer of rp122 to the nucleus greatly preceded its loss from the chloroplast and involved the gain of an intron," $E M B O J$ 10:3073-3078 (1991)). Three partial clones were obtained with inserts greater than $1600 \mathrm{bp}$ in length. Complete sequence analysis of the three clones showed that the nucleotide sequence of all clones were identical. The sequence of the PCR-derived CDNA was identical to the $\lambda$ gt10 cDNAs except for the incorrect identification of Thr-249 as an Asn during peptide sequencing of pepsin fragment P14. The longest clone (1775 bp in length) lacked only a portion of the 5 -untranslated region. The remainder of the 5'-untranslated region was obtained by PCR-RACE. The 515 bp PCR-RACE product was barely detectable on ethidium-stained gels which likely reflects the low abundance of the rbcMT mRNA in pea. Sequence analysis confirmed the identity of the PCR-RACE product as encoding for the predicted 5' portion of rbcMT including the remainder of the 5'-untranslated region. In the region where the PCR-RACE product overlapped the cloned cDNA of rbcMT, complete sequence identity was observed (SEQ. ID NO. 41 . position $31-484 \mathrm{bp}$ ). Given these overlapping 55 clones, the present inventor was able to assemble the sequence of the rbcMT cDNA as shown in SEQ. ID NO. 41. All of the peptic polypeptide sequences obtained from affinity-purified Rubisco LSMT were identified in the translated open-reading frame of the rbcMT cDNA.

The rbcMT cDNA of 1802 bp in length contained a 5 leader of 58-nucleotides which contained several short repeat elements and a 3'-untranslated region of 276nucleotides. The rbcMT cDNA encoded for a protein of 489-amino acid residues with a predicted molecular mass of $55 \mathrm{kDa}$. Examination of the amino terminus of Rubisco LSMT revealed several motifs that commonly appear in
16

chloroplast transit-peptide sequences, such as an abundance of hydroxylated amino acids Ser and Thr, presence of small hydrophobic amino acids, and general lack of acidic amino acids (Keegstra et al, "Chloroplastic precursors and their transport across the envelope membranes." Annu. Rev. Plant. Physiol. Plant. Mol. Biol. 40:471-501 (1989); and Theg et al. "Protein import into chloroplasts." Trends in Cell Biology 3:186-190 (1993)). Given that N-terminal sequence information could not be obtained for Rubisco LSMT, and 10 that there is as yet no amino acid consensus sequence or secondary structural motif which unambiguously identifies the processing site for removal of chloroplast transit sequences (von Heijne et al. "Chloroplast transit peptides: The perfect random coil?" FEBS Lat. 278(1):1-3 (1991)), 15 the cleavage site between the precursor and mature forms of Rubisco LSMT could not be determined.

Comparison of the deduced amino acid sequence of rbcMT cDNA with protein carboxyl methyltransferases from wheat (D-aspartyl/L-isoaspartyl protein 20 methlytransferase. Mudgett et al, "Characterization of plant L-isoaspartyl methyltransferases that may be involved in seed survival: Purification, cloning, and sequence analysis of the wheat germ enzyme." Biochemistry 32:11100-11111 (1993)) and $E$. coli (gamma-glutamyl carboxyl 25 methyltransferase. Mutoh et al, "Nucleotide sequence corresponding to five chemotaxis genes in Escherichia coli," J. Bacteriol. 165:161-166 (1986)) showed a low alignment score with sequence identity on the order of $10 \%$ (gaps in the sequence were introduced to maximize alignment). Three

30 short amino acid regions (8 to 10 residues) of sequence similarity have been reported for several protein and smallmolecule AdoMet-dependent methyltransferases (Kagan et al. "Widespread occurrence of three sequence motifs in diverse S-adenosylmethionine-dependent methyltrans35 ferases suggests a common structure for these enzymes." Anch. Biochem. Biophy. 310(2):417-427 (1994)). Using manual alignment, none of the three proposed sequence motifs of AdoMet-dependent methyltransferases were detected in Rubisco rbcMT. In a search of the Swissprot and

40 NBRF-PIR data banks. the best match for Rubisco rbcMT was AfsR protein of Streptomyces coelicolor which reflected a $23 \%$ sequence identity over the entire protein. again with considerable gaps introduced.

\section{5}

\section{Example 10}

\section{DNA analysis}

To obtain information on gene copy number, total pea leaf DNA was isolated and digested with several different restriction endonucleases (FIG. 3). A 1775 bp rbcMT cDNA probe hybridized to two EcoR I DNA fragments. approximately $5.3 \mathrm{kbp}$ and $2.0 \mathrm{kbp}$ (one EcoR I restriction endonuclease site is located within the sequenced cDNA). Two bands, approximately $3.5 \mathrm{kbp}$ and $1.3 \mathrm{kbp}$, were observed after cleavage with Dra I, while a single band of $3.7 \mathrm{kbp}$ was observed after DNA-digestion with Hind III. The simplicity of the DNA restriction digest pattern suggests that the gene copy number per haploid genome is low for rbcMT.

\section{Example 11}

\section{RNA analyses}

Northern blot analyses were conducted on pea tissues to examine several developmental and organ-specific parameters governing rbcMT gene expression. As a basis for 5 comparison, the expression of genes encoding Rubisco small (rbcS) and large (rbcL) subunit were concomitantly examined. The rbcS gene family and rbcL gene were exam- 
17

ined in an attempt to determine whether the expression of the Rubisco subunits and Rubisco LSMT was coordinated. Northern blot analysis indicated that the rbcMT gene encoded for a single species of mRNA of approximately 1.8 $\mathrm{kb}$ in length (see FIG. 4). Examination of organ-specific expression showed that accumulation of the rbcMT transcript paralleled the accumulation of rbcL and rbcS mRNA with the greatest proportion of mRNA being localized in green leaf tissue. Transcripts encoding rbcS, rbcL and rbcMT were detected in pea stems, though the level of expression was 7. 10. and 28 -fold lower, respectively, than in green leaves. The quantity of rbcMT, rbcS, and rbcL mRNA in root tissue was below the level of Northern blot sensitivity. Maximum extractable Rubisco LSMT activity generally paralleled the accumulation of rbcMT mRNA. though the enzyme activity detected in stems was greater than would be predicted based on mRNA levels. Maximum extractable Rubisco LSMT activity of roots, stems, and green leaves was 2.15 , and 36 pmoles $\mathrm{CH}_{3} \cdot \mathrm{min}^{-1} \cdot \mathrm{mg}$ protein $^{-1}$, respectively. Finally, it should be noted that the exposure times of the rbcMT, rbcS, and rbcL Northern analyses differ considerably and hence should be considered when comparing the absolute amounts of each transcript. The exposure time of rbcMT Northern analyses were consistently 25- to 50-times longer than that of $\mathrm{rbcL}$ or $\mathrm{rbcS}$, suggesting that rbcMT transcripts do not accumulate to the level of the Rubisco subunits.

Examination of the accumulation of rbcMT mRNA during the greening of pea leaves is shown in FIG. 5. A low level of rbcMT mRNA was detected in 8-day-old dark-grown pea leaves (lane 1). Upon illumination of etiolated peas. rbcMT transcript levels increased -3 -fold after 24 hours of illumination and then declined slightly after an additional 48 hours of development in the light (lanes 2-3). The maximum
18

extractable activity of Rubisco LSMT enzyme increased during the greening of dark-grown peas from 11 pmoles $\mathrm{CH}_{3} \cdot \mathrm{min}^{-1} \cdot \mathrm{mg}$ protein ${ }^{-1}$ in dark-grown leaves to an apparent maximum of 32.5 pmoles $\mathrm{CH}_{3} \cdot \mathrm{min}^{-1} \cdot \mathrm{mg} \mathrm{protein}^{-1}$ after

572 hours illumination. This level of extractable Rubisco LSMT enzyme activity was similar to that observed $(32.4$ pmoles $\mathrm{CH}_{3} \cdot \mathrm{min}-1 \cdot \mathrm{mg} \mathrm{protein}^{-1}$ ) for peas grown eight days under continuous illumination. Interestingly. the level of rbcMT mRNA in continuous illuminated leaves was signifi10 cantly lower than the levels observed during the early stages of greening of pea (lanes 2-3 vs. 4). In fact, levels of rbcMT mRNA from continuous illuminated plants was not visibly different from dark-grown leaves. As expected, rbcS and rbcL transcript levels also increased upon illumination of 15 dark-grown seedlings. In contrast to rbcMT. transcripts of $\mathrm{rbcS}$ and rbcL reached an apparent maximum during the latter stages of greening (lane 3). In addition, rbcS and rbcL transcript levels remained elevated in leaves grown under continuous illumination (lane 4). These results indicate that. 20 unlike rbcS and rbcL, transcript levels for rbcMT reach an apparent maximum during the early stages of light-induced leaf development and decline in mature light-grown leaf tissue. These changes in transcript levels would be expected for an enzyme whose function involves post-translational 25 protein processing.

All of the references cited herein are effectively incorporated by reference to the same extent as if each individually had been incorporated by reference.

Other embodiments of the invention will be apparent to those skilled in the art from consideration of the specification and practice of the invention disclosed herein. It is intended that the specification and examples be considered as exemplary only, with the true scope and spirit of the invention being indicated by the following claims.

SEQUENCE LISTING

( 1 ) GENERAL INFORMATION:

( $i$ i i ) NUMBER OF SEQUENCES: 41

( 2 ) INFORMATION FOR SEQ ID NO:1:

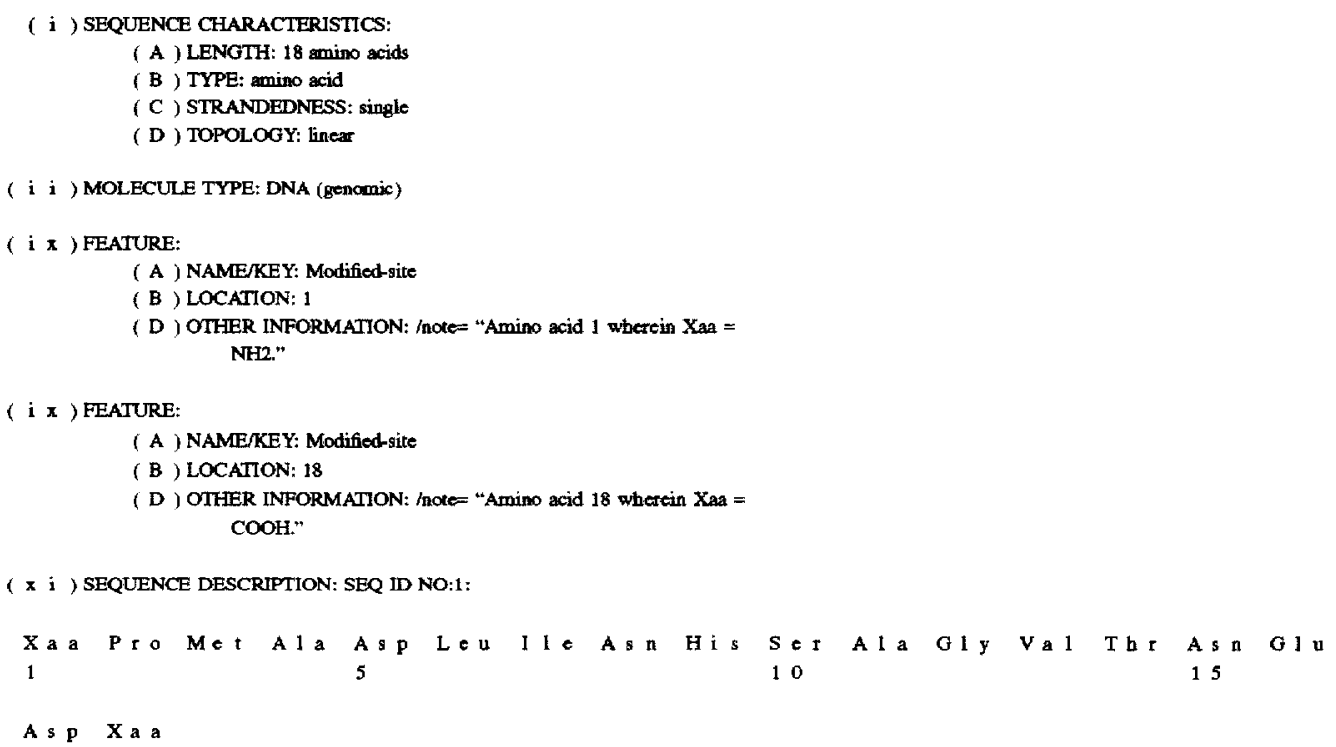




\section{$5,723,752$}

( 2 ) INFORMATION FOR SEQ ID NO:2:

( i ) SEQUENCE CHARACTERISTICS:
(A) LENGTH: 48 base pairs
(B ) TYPE: mucleic acid
(C) STRANDEDNESS: single
(D) TOPOLOCY: linear

(i i ) MOLECULE TYPE: DNA (genomic)

( $x$ i ) SEQUENCE DESCRIPTION: SEQ ID NO:2:

CCAATGGCAG ATTTAATAA TCATTCAGCA GGAGTAACAA ATGAAGT

( 2 ) INFORMATION FOR SEQ ID NO:3:

( i ) SEQUENCE CHARACTERISTICS:

$$
\begin{aligned}
& \text { ( A ) LENGTH: } 48 \text { base pairs } \\
& \text { (B ) TYPE: mucleic acid } \\
& \text { (C) STRANDEDNESS: single } \\
& \text { (D) TOPOLOGY: linear }
\end{aligned}
$$

( i i ) MOLECULE TYPE: DNA (genomic)

( $x$ i ) SEQUENCE DESCRIPTION: SEQ ID NO:3:

( 2 ) INFORMATION FOR SEQ ID NO:4:

(i ) SEQUENCE CHARACTERISTICS:

$$
\begin{aligned}
& \text { (A) LENGTH: } 48 \text { base pairs } \\
& \text { (B ) TYPE: nucleic seid } \\
& \text { (C) STRANDEDNESS: single } \\
& \text { (D) TOPOLOGY: limear }
\end{aligned}
$$

( $\mathrm{i}$ i ) MOLECULE TYPE: DNA (genomic)

( $x$ i ) SEQUENCE DESCRIPIION: SEQ ID NO:4:

( 2 ) INFORMATION POR SEQ ID NO:5:

$$
\begin{aligned}
& \text { (i ) SEQUENCE CHARACTERISTICS: } \\
& \text { (A) LENGTH: } 48 \text { base pairs } \\
& \text { ( B ) TYPE: nucleic acid } \\
& \text { (C) STRANDEDNESS: single } \\
& \text { (D) TOPOLOGY: linear }
\end{aligned}
$$

( $i$ i ) MOLECULE TYPE: DNA (genomic)

( $x$ i ) SEQUENCE DESCRIPTION: SEQ ID NO:5:

( 2 ) INFORMATION FOR SEQ ID NO:6:

(i ) SEQUENCE CHARACTERISTICS:

$$
\begin{aligned}
& \text { ( A LENGTH: } 48 \text { base pairs } \\
& \text { (B ) TYPE: nucleic acid } \\
& \text { (C) STRANDEDNESS: single } \\
& \text { (D) TOPOLOGY: linear }
\end{aligned}
$$

( i i ) MOLECULE TYPE: DNA (genomic)

( $x$ i ) SEQUENCE DESCRIPTION: SEQ TD NO:6:

( 2 ) INFORMATION FOR SEQ ID NO:7:

( i ) SEQUENCE CHARACTERISTICS: 
-continued

\begin{abstract}
(A ) LENGTH: 48 base pairs
( B ) TYPE: mucleic acid

(C) STRANDEDNESS: single

(D) TOPOLOGY: linear
\end{abstract}

( $i$ i ) MOLECULE TYPE: DNA (genomic)

( $x$ i ) SEQUENCE DESCRIPTION: SEQ ID NO:7:

CCTATGGCTG ACCTTATCAA CCACAGCGCT GGTGTTACTA ACGAGGAC

( 2 ) INFORMATION FOR SEQ ID NO:8:

(i) SEQUENCE CHARACTERISTICS:

(A) LENGTH: 39 base pairs
(B ) TYPE: nucleic acid
(C) STRANDEDNESS: single
(D ) TOPOLOGY: linear

( $\mathrm{i}$ i ) MOLECULE TYPE: DNA (Benomic)

( $i \times)$ FEATURE:
(A ) NAME/KEY: misc_feature
(B) LOCATION: 6.30
(D) OTHER INFORMATION: /note= "Nucleotides 6, 9, 16, 18,
$21,24,27$ and 30 wherein $\mathrm{N}=\mathrm{I}$,"

( $x$ i ) SEQUENCE DESCRIPTION: SEQ ID NO:8:

GATTTNATNA ATCATNCNGC NGGNGTNACN AATGAAGAT

( 2 ) INFORMATION FOR SEQ ID NO:9

( i ) SEQUENCE CHARACTERISTICS
(A) LENGTH: 39 bese pair
(B) TYPE: mucleic acid
(C) STRANDEDNESS: single
(D) TOPOLOGY: linear

( i i ) MOLECULE TYPE: DNA (genomic)

( i $\times$ ) FEATURE:

( A ) NAME/KEY: misc_feanure

(B) LOCATION: 6.30

( D ) OTHER INFORMATION: fnote= "Nucleotides 6, 9, 16, 18,

$21,24,27$ and 30 wherein $\mathrm{N}=1$."

( $x$ i ) SEQUENCE DESCRIPTION: SEQ ID NO:9:

GATTTNATNATCATNGNGC NGGNGTNACN AACGAGGAC

( 2 ) INFORMATION FOR SEQ ID NO:10:

(i ) SEQUENCE CHARACTERISTICS:
(A.) LENGTH: 48 base pairs
(B) TYPE: mucleic acid
(C ) STRANDEDNESS: single
(D ) TOPOLOGY: linear

( $\mathrm{i}$ i ) MOLECULE TYPE: DNA (genomic)

$(x$ i ) SEQUENCE DESCRIPTION: SEQ D NO:10

GGGTACCGTC TAAATTAAT AGTAAGTCG CCTCATTGTT TACTTCTA

( 2 ) INFORMATION FOR SEQ ID NO:11:

(i) SEQUENCE CHARACTERISTICS:
(A) LENGTH: 48 base pair
(B) TYPE: mucleic acid
(C) STRANDEDNESS: single
(D) TOPOLOGY: linear

(i i ) MOLECULE TYPE: DNA (genomic)

( $x$ i ) SEQUENCE DESCRIPTION: SEQ ID NO:11: 


\section{$5,723,752$}

-continued

GGCTACCGGC TGAACTATTI GGTGAGGCGG CCGCAGTGGT TGCICCTG

( 2 ) INPORMATION FOR SEQ ID NO:12:

(i) SEQUENCE CHARACTERISTICS:
(A ) LENGTH: 48 base peira
(B) TYPE: tuucleic acid
(C ) STRANDEDNESS: single
(D ) TOPOLOOY: linear

(i i ) MOLECULE TYPE: DNA (genomic)

( $x$ i ) SEQUENCE DESCRIPTION: SEQ ID NO:12:

GGATACCGCC TGGATTAGTI OGTGAGCCOC CCCCACTGCT TGCTCCTG

( 2 ) INFORMATION FOR SEQ ID NO:13:

(i ) SEQUENCE CHARACTERISTICS

(A) LENGTH: 48 base pairs
(B) TYPE: nucleic acid
(C) STRANDEDNESS: single
(D) TOPOLOGY: liver

( $\mathrm{i}$ i ) MOLECULE TYPE: DNA (genomic)

( $x$ i ) SEQUENCE DESCRIPIION: SEQ ID NO:13:

GGTTACCGAC TOGAGTAGTT GGTGAGACGA CCACAATGAT TGCTCCTG

( 2 ) INFORMATION FOR SEQ ID NO:14:

(i) SEQUENCE CHARACTERISTICS:
A ) LENGIH: 48 base pritr
(B ) TYPE: nucleic acid
(C) STRANDEDNESS: single
(D) TOPOLOGY: limear

( i i ) MOLECULE TYPE: DNA (genomic)

( $x$ i ) SEQUENCE DESCRIPIION: SEQ ID NO:14:

GGT IACCGAC TGGACTAGTT GGTGTCACOA CCACAATGAT TGCTCCTG

( 2 ) INFORMATION FOR SEQ ID NO:15:

(i) SEQUENCE CHARACTERISTICS:
(A) LENGTH: 48 base pairs
(B) TYPE: nucleic acid
(C) STRANDEDNESS: single
(D) TOPOLOGY: linear

( 1 i ) MOLECULE TYPE: DNA (gemomic)

( $x$ i ) SEQUENCE DESCRIPTION: SEQ ID NO:15:

GGTTACCGAC TGGAATATT GGTGTCGCGA CCACAATGAT TGCTCCTG

( 2 ) INFORMATION FOR SEQ ID NO:16:

( i ) SEQUENCE CHARACTERISTICS:
(A) LENGTH: 39 base pair
(B) TYPE: nucleic acid
(C) STRANDEDNESS: single
(D) TOPOLOGY: linear

(i i ) MOLECULE TYPE: DNA (genomic)

( $i \times$ ) FEATURE:

\footnotetext{
(A) NAME/KEY: misc feature

(B) LOCATION: 12.36

(D) OTHER INFORMATION: inote= "Nucleotides 12, 15, 22, 24, $27,30,33$ and 36 wherein $N=I . "$
} 


\section{$5,723.752$}

-continued

( $x$ i ) SEQUENCE DESCRIPTION: SEQ ID NO:16:

IACCGGCTAG ANTANTTGGT GNGNCGNCCN CANTGNTTG

( 2 ) INFORMATION FOR SEQ ID NO:17:

( i ) SEQUENCE CHARACTERISTICS:

(A) LENGTH: 39 base pairs

(B ) TYPE: nucleic acid

(C) STRANDEDNESS: aingle

(D) TOPOLOOY: linear

( $i$ i ) MOLECULE TYPE: DNA (genomic)

(i $x$ ) FEATURE
( A ) NAME/KEY: misc_fearure
(B ) LOCATION: 12.36
(D) OTHER INFORMATION: /note= "Nucleotides 12, 15, 22, 24,
$27,30,33$ and 36 wherein $\mathrm{N}=\mathrm{I}$.

( $x$ i ) SEQUENCE DESCRIPIION: SEQ ID NO:17

TACCGCCTCG ANTANTTGGT GNCNCGNCCN CANTGNTTG

( 2 ) INFORMATION FOR SEQ ID NO:18:

(i ) SEQUENCE CHARACTERISTICS:

(A ) LENGTH: 39 hase pairs

(B) TYPE: nucleic acid

(C ) STRANDEDNESS: single

(D) TOPOLOGY: linear

( i i ) MOLECULE TYPE: DNA (genomic)

( i $\times$ ) FEATURE
( A ) NAME/KEY: misc_featur
(B) LOCATION: 12,36
(D) OTHER INFORMATION: inote= "Nucleotides 12, 15, 22, 24, $27.30,33$ and 36 wherein $\mathrm{N}=\mathrm{I}$."

( $x$ i ) SEQUENCE DESCRIPTION: SEQ ID NO:18:

( 2 ) INFORMATION FOR SEQ ID NO:19

(i ) SEQUENCE CHARACTERISTICS:
(A ) LENGTH: 39 base pair
(B) TYPE: nucleic acid
(C) STRANDEDNESS: single
(D) TOPOLOGY: linear

( i i ) MOLECULE TYPE: DNA (genomic)

( i $\times$ ) FEATURE:
(A ) NAME/KEY: misc_feanur
( B ) LOCATION: 12.36
(D) OTHER INFORMATION: /note= "Nucleotides 12, 15, 22, 24, $27,30,33$ and 36 wberein $N=1 . "$

( $x$ i ) SEQUENCE DESCRIPTION: SEQ ID NO:19:

TACCGTCTCG ANTANTTGGT GNCNCGNCCN CANTGNTTG

( 2 ) INFORMATION FOR SEQ ID NO:20:

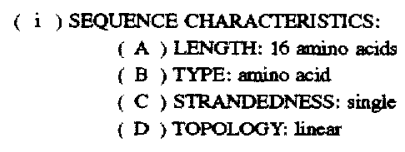

( $\mathrm{i}$ i ) MOLECULE TYPE: DNA (genomic)

( $i \times)$ FEATURE:

( A ) NAME'KEY: Modified-site 
-continued

(B ) LOCATION: 1

(D ) OTHER INFORMATION: /note= "Amino acid 1 wherein Xas = NH2."

( $i$ × ) FEATURE:
(A) NAME/KEY: Modified-site
(B ) LOCATION: 16
(D) OTHER INFORMATION: /note= "Amino acid 16 wherein Xaa = COOH."

( $x$ i ) SEQUENCE DESCRIPTION: SEQ ID NO:20:

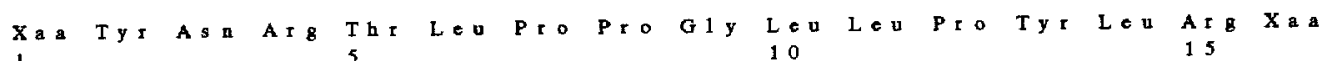

( 2 ) INFORMATION FOR SEQ ID NO:21:

(i) SEQUENCE CHARACTERISTICS

(A ) LENGTH: 42 base pairs
(B ) TYPE: mucleic acid
(C) STRANDEDNESS: single
(D ) TOPOLOGY: linear

( $\mathrm{i}$ i ) MOLECULE TYPE: DNA (genomic)

( $x$ i ) SEQUENCE DESCRIPTION: SEQ ID NO:21:

TATAATCOA CATTACCACC AGGATTATTA CCATATTAC GA

( 2 ) INFORMATION FOR SEQ ID NO:22:

( $i$ ) SEQUENCE CHARACTERISTICS:
(A) LENGTH: 42 hase pairs
(B) TYPE: nucleic acid
(C) STRANDEDNESS: single
(D ) TOPOLOGY: linear

( $\mathrm{i}$ i ) MOLECULE TYPE: DNA (gencmic)

( $x$ i ) SEQUENCE DESCRIPTION: SEQ ID NO:22:

TACAACCGCA CCITGCCCCC CGGCTTGTTG CCCTACTTGC GC

( 2 ) INFORMATION FOR SEQ ID NO:23:

( i ) SEQUENCE CHARACTERISTICS:
A ) LENGTH: 42 base pairs
(B) TYPE: nucleic acid
(C) STRANDEDNESS: single
(D) TOPOLOGY: linear

( i i ) MOLECULE TYPE: DNA (genomic)

( $x$ i ) SEQUENCE DESCRIPTION: SEQ ID NO:23:

TACAACCGGA CGCTACCGCC GGGGCTACTA CCGTACCTAC GG

( 2 ) INFORMATION FOR SEQ ID NO:24:

( i ) SEQUENCE CHARACTERISTICS:
(A ) LENGTH: 42 base peirs
(B) TYPE: nucleic acid
(C) STRANDEDNESS: single
(D ) TOPOLOGY: linear

( i i ) MOLECULE TYPE: DNA (genomic)

( $x$ i ) SEQUENCE DESCRIPTION: SEQ D NO:24

TACAACCGTA CTCTCCCTCC TGGTCTCCTC CCTTACCTCC GT

( 2 ) INFORMATION FOR SEQ ID NO:25:

(i ) SEQUENCE CHARACTERISTICS:

(A ) LENGTH: $\mathbf{4 2}$ base pairs 


\section{$5,723,752$}

-continued

(B) TYPE: nucleic acid

(C ) STRANDEDNESS: single

(D ) TOPOLOGY: linear

( $i$ i ) MOLECULE TYPE: DNA (genomic)

( $x$ i ) SEQUENCE DESCRIPTION: SEQ ID NO:25:

( 2 ) INFORMATION FOR SEQ ID NO:26:

( i ) SEQUENCE CHARACTERISTICS:
(A ) LENGTH: 42 base pair
(B ) TYPE: mucleic acid
(C) STRANDEDNESS: single
(D) TOPOLOGY: linear

( $\mathrm{i}$ i ) MOLECUIE TYPE: DNA (genomic)

( $x$ i ) SEQUENCE DESCRIPTION: SEQ ID NO:26

TACAACAGGA CTCTTCCTCC TGGTCTTCTT CCTTACCTTA GG

( 2 ) INFORMATION FOR SEQ ID NO:27:

( i ) SEQUENCE CHARACTERISTICS:

(A ) LENGTH: 35 base pairs

(B ) TYPE: mucleic acid

(C) STRANDEDNESS: single

(D) TOPOLOGY: linear

( $\mathrm{i}$ i ) MOLECULE TYPE: DNA (genomic)

( i $\pi$ ) FEATURE:
( A ) NAME/KEY: misc_fearure
(B ) LOCATION: 6.27
(D) OTHER INFORMATION: inote= "Nucleotides 6, 9,12, 15,
$18,21,24$ and 27 wherein $\mathrm{N}=\mathrm{L}^{\prime \prime}$

( $x$ i ) SEQUENCE DESCRIPIION: SEQ ID NO:27:

( 2 ) NNFORMATION FOR SEQ ID NO:28:

(i ) SEQUENCE CHARACTERISTICS:
(A ) LENGTH: 35 base pair
( B ) TYPE: nucleic acic
(C) STRANDEDNESS: single
( D ) TOPOLOGY: linear

( $\mathrm{i}$ i ) MOLECULE TYPE: DNA (genomic)

( i x ) FEATURE:
( A ) NAME/KEY: misc_feahume
(B) LOCATION: 6.27
(D ) OTHER INFORMATION: inote= "Nucleotides 6, 9, 12, 15, $18,21,24$ and 27 wherein $\mathrm{N}=\mathrm{I} . "$

$(x$ i $)$ SEQUENCE DESCRIPIION: SEQ ID NO:28:

AATAGNACNT TNCCNCCNGG NTTNTTNCCC TACCT

( 2 ) INFORMATION FOR SEQ ID NO:29:

(i ) SEQUENCE CHARACTERISTICS:
(A ) LENGTH: 35 base pair
(B ) TYPE: nucleic acid
(C) STRANDEDNESS: single
(D) TOPOLOGY: linear

( $i$ i ) MOLECULE TYPE: DNA (genomic)

( i $x$ ) FEATURE:

( A ) NAMEKEY: misc_feature 


\section{$5,723,752$}

-continued

(B ) LOCATION: 6.27

(D) OTHER INFORMATION: /note= Nuclootides 6,9,. 12, 15, $18,21,24$ and 27 wherein $N=I$."

( $x$ i ) SEQUENCE DESCRIPTION: SEQ ID NO:29:

AATAGNACNT TNCCNCCNGG NTTNTTNCCG TACCT

( 2 ) INFORMATION FOR SEQ ID NO:30:

(i) SEQUENCE CHARACTERISTICS:
A ) LENGTH; 35 base pairs
(B) TYPE: mucleic acid
(C) STRANDEDNESS: single
(D) TOPOLOGY: linear

( i i ) MOLECULE TYPE: DNA (genomic)

( i a ) FEATURE
(A ) NAME/KEY: misc feature
(B ) LOCATION: 6.27
(D) OTHER INFORMATION: /note= "Nucleotides 6,9, 12, 15, $18,21,24$ and 27 wherein $\mathrm{N}=\mathrm{I}$."

( $x$ i ) SEQUENCE DESCRIPTION: SEQ ID NO:30:

( 2 ) INFORMATION FOR SEQ ID NO:31:

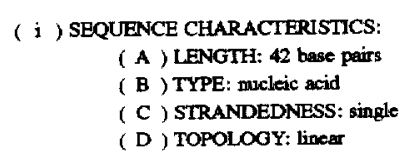

( $\mathrm{i}$ i ) MOLECULE TYPE: DNA (genomic)

( $x$ i ) SEQUENCE DESCRIPTION: SEQ ID NO:31:

ATATTAGTT GTAAGGTGG TCCTAATAAT GGTATAAATG CT

( 2 ) INFORMATION FOR SEQ ID NO:32:

( $j$ ) SEQUENCE CHARACTERISTICS:
(A) LENOTH: 42 base pairs
( B ) TYPE: nucleic acid
(C) STRANDEDNESS: single
(D) TOPOLOGY: linear

( $i$ i ) MOLECULE TYPE: DNA (genomic)

$(x$ i ) SEQUENCE DESCRIPTION: SEQ ID NO:32:

ATGTTGGCGT GGAACGGGGG OCCGAACAAC GGGATGAACG CG

( 2 ) INFORMATION FOR SEQ ID NO:33:

(i ) SEQUENCE CHARACTERISTICS

$$
\begin{aligned}
& \text { ( A ) LENGTH: } 42 \text { base pairs } \\
& \text { (B ) TYPE: mucleic acid } \\
& \text { (C ) STRANDEDNESS: single } \\
& \text { (D ) TOPOLOGY: liner }
\end{aligned}
$$

( $\mathrm{i}$ i ) MOLECULE TYPE: DNA (genomic)

( $x$ i ) SEQUENCE DESCRIPTION: SEQ ID NO:33:

( 2 ) INFORMATION FOR SEQ ID NO:34:

(i ) SEQUENCE CHARACTERISTICS:

(A.) LENOTH: 42 base pairs

( B ) TYPE: mucleic acid 
-continued

(C) STRANDEDNESS: singlo

(D) TOPOLOGY: linear

( $\mathrm{i}$ i ) MOLECULE TYPE: DNA (genomic)

( $x$ i ) SEQUENCE DESCRIPTION: SEQ ID NO:34:

ATGTTGGCA GAGAGGGAGG ACCAGAGGAG GGAATGAGG CA

( 2 ) INFORMATION FOR SEQ ID NO:35

(i ) SEQUENCE CHARACTERISTICS:

$$
\begin{aligned}
& \text { ( A ) LENGTH: } 42 \text { bese pairs } \\
& \text { ( B ) TYPE: nucleic acid } \\
& \text { (C) STRANDEDNESS: single } \\
& \text { (D ) TOPOLOGY: linear }
\end{aligned}
$$

( i i ) MOLECULE TYPE: DNA (genomic)

( $x$ i ) SEQUENCE DESCRIPTION: SEQ ID NO:35:

( 2 ) INFORMATION FOR SEQ ID NO:36:

(i) SEQUENCE CHARACTERISTICS

$$
\begin{aligned}
& \text { (A ) LENGTH: } 42 \text { base pairs } \\
& \text { (B) TYPE: nucleic acid } \\
& \text { (C ) STRANDEDNESS: single } \\
& \text { (D) TOPOLOGY: linear }
\end{aligned}
$$

( i i ) MOLECULE TYPE: DNA (genomic)

( $x$ i ) SEQUENCE DESCRIPTION: SEQ ID NO:36:

( 2 ) INFORMATION FOR SEQ ID NO:37:

(i ) SEQUENCE CHARACTERISTICS:

$$
\begin{aligned}
& \text { (A) LENGTH: } 36 \text { base pairs } \\
& \text { (B) TYPE: nucleic acid } \\
& \text { (C) STRANDEDNESS: single } \\
& \text { (D) TOPOLOGY: linear }
\end{aligned}
$$

( i i ) MOLECULE TYPE: DNA (genomic)

(i $\pi$ ) FEATURE:
(A ) NAMEKKEY: misc_feature
(B) LOCATION: 9.33
(D) OTHER INFORMATION: /note= "Nucleotides 9, 12, 15, 18, $21,24,27,30$ and 33 wherein $\mathrm{N}=\mathrm{L}$."

$(x$ i ) SEQUENCE DESCRIPTION: SEQ ID NO:37:

( 2 ) INFORMATION FOR SEQ ID NO:38:

$$
\begin{aligned}
& \text { ( i) SEQUENCE CHARACTERISTICS: } \\
& \text { (A) LENGTH: } 36 \text { base pairs } \\
& \text { ( B ) TYPE: nucleic acid } \\
& \text { (C) STRANDEDNESS: single } \\
& \text { ( D ) TOPOLOGY: linear }
\end{aligned}
$$

( $i$ i ) MOLECULE TYPE: DNA (genomic)

(i $x$ ) FEATURE:

$$
\begin{aligned}
& \text { (A ) NAMEIKEY: misc_feature } \\
& \text { (B) LOCATION: } 9.33 \\
& \text { (D) OTHER INFORMATION: tnote= 'Nucleccides } 9,12,15,18 \text {, } \\
& 21,24,27,30 \text { and } 33 \text { wherein } N=I \text {." }
\end{aligned}
$$

( $\times$ i ) SEQUENCE DESCRIPTION: SEQ ID NO:38: 
-continued

(2) INFORMATION FOR SEQ ID NO:39:

(i ) SEQUENCE CHARACTERISTCS:
(A) LENGTH: 24 base pain
(B) TYPE: raclecic acid
(C) STRANDEDNESS: single
(D ) TOPOLOOY: linear

( i i ) MOLECULE TYPE: DNA (genomic)

( $x$ i ) SEQUENCE DESCRIPTION: SEQ ID NO:39:

CCAAAAGAG TCATCCAGCG TCAC

( 2 ) INFORMATION FOR SEQ ID NO:40:

( i ) SEQUENCE CHARACTERISTICS:

$$
\begin{aligned}
& \text { (A) LENGTH: } 36 \text { base peirs } \\
& \text { (B) TYPE: nucleic acid } \\
& \text { (C) STRANDEDNESS: single } \\
& \text { ( D ) TOPOLOGY: linear }
\end{aligned}
$$

( i i ) MOLECUIE TYPE: DNA (genomic)

( $x$ i ) SEQUENCE DESCRIPTION: SEQ ID NO:40:

( 2 ) INFORMATION FOR SEQ ID NO:41:

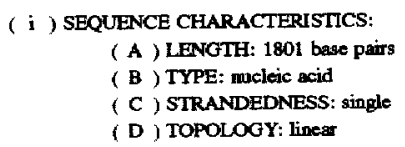

( i i ) MOLECULE TYPE: DNA (genomic)

( i $x$ ) FEATURE:

(A ) NAME/KEY: CDS

(B) LOCATON: $59 . .1528$

( $x$ i ) SEQUENCE DESCRIPTION: SEQ D NO:41:

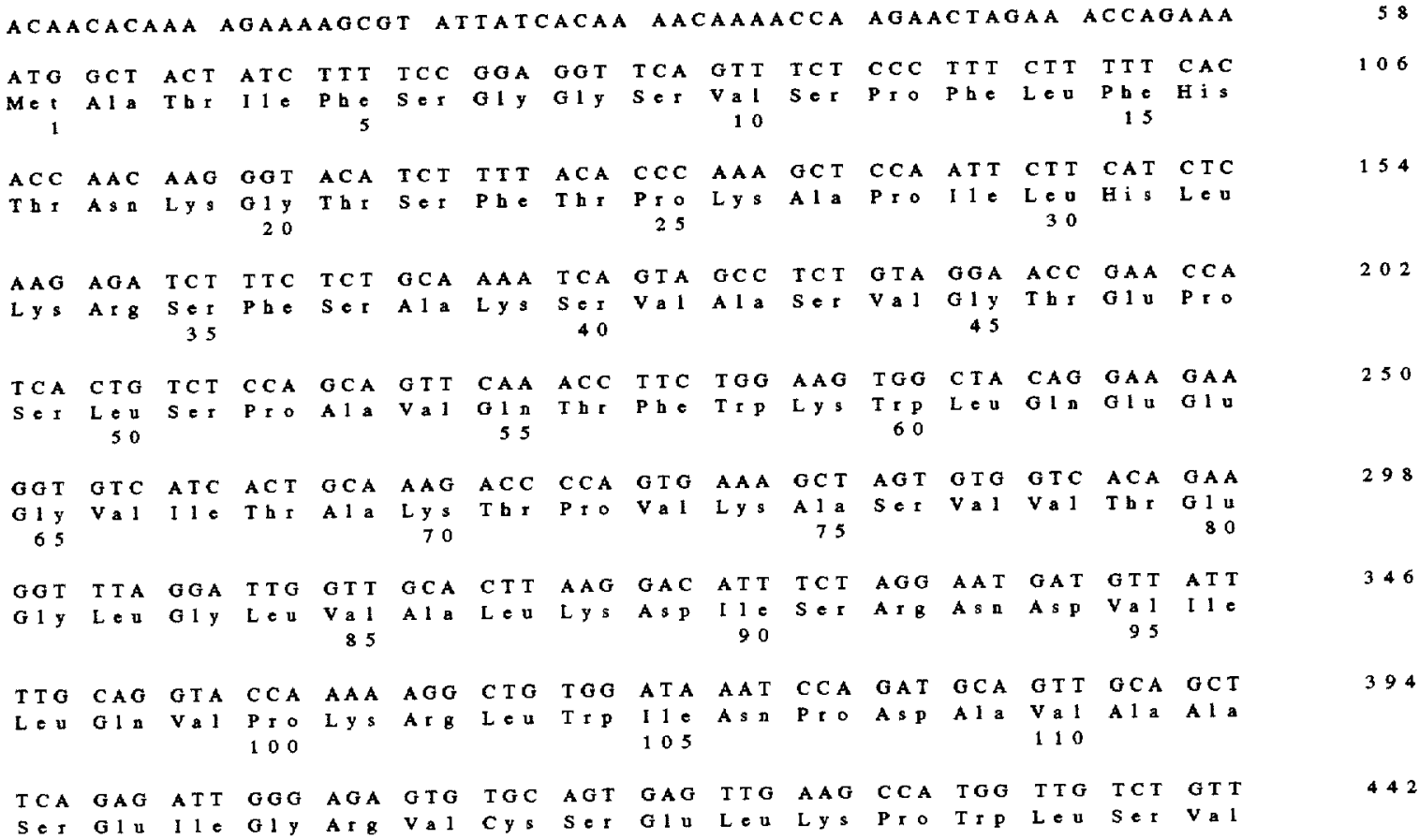




\section{$5,723,752$}

-continued

\begin{tabular}{|c|c|c|c|c|c|c|c|c|c|c|c|c|c|c|c|c|}
\hline & & 115 & & & & & 120 & & & & & 125 & & & & \\
\hline $\begin{array}{l}\text { A T A } \\
1 \\
1\end{array}$ & $\begin{array}{lll}C & T & C \\
L & C & 0 \\
1 & 3 & 0\end{array}$ & $\begin{array}{l}\text { T T I } \\
\text { P he }\end{array}$ & $\begin{array}{l}C T \\
L \\
L\end{array}$ & $\begin{array}{cc}\text { A T A } \\
\text { I } 1\end{array}$ & $\begin{array}{l}A G \mathbf{A} \\
A \times \mathbf{B}\end{array}$ & $\begin{array}{lll}G & A & G \\
G & 1 & u \\
1 & 3 & 5\end{array}$ & $\begin{array}{l}A G G \\
A \times g\end{array}$ & $\begin{array}{l}T C A \\
S \in \mathbb{A}\end{array}$ & $\begin{array}{l}A O G \\
A \times \&\end{array}$ & $\begin{array}{l}\text { GAA } \\
\text { G1 }\end{array}$ & $\begin{array}{l}G A T \\
A \& p \\
140\end{array}$ & $\begin{array}{l}\text { TCT } \\
\text { SEI }\end{array}$ & $\begin{array}{l}\text { G T T } \\
\text { V a } 1\end{array}$ & $\begin{array}{l}T G G \\
T \times p\end{array}$ & $\begin{array}{l}\mathrm{AAG}_{\mathrm{A}} \\
\mathrm{L}_{\mathrm{YS}} \mathrm{s}\end{array}$ & 490 \\
\hline $\begin{array}{ccc}C A & C \\
H & \text { i s } \\
1 & 4 & 5\end{array}$ & $\begin{array}{l}\text { TAT } \\
\text { Ty }\end{array}$ & $\begin{array}{l}\text { T T T } \\
\text { P h e }\end{array}$ & $\begin{array}{l}\text { GG T } \\
\text { GIY }\end{array}$ & $\begin{array}{ll}\text { A T T } \\
\text { I }\end{array}$ & $\begin{array}{lll}C & T \\
L & \in & 0 \\
1 & 5 & 0\end{array}$ & $\begin{array}{l}C C A \\
P=0\end{array}$ & $\begin{array}{l}\mathrm{CAG} \\
\mathbf{G} 1 \mathrm{n}\end{array}$ & $\begin{array}{l}\text { GAA } \\
\text { G } 1 \mathrm{u}\end{array}$ & $\begin{array}{l}\text { AC T } \\
\text { T h I }\end{array}$ & $\begin{array}{r}G A T \\
A \text { s p } \\
155\end{array}$ & $\begin{array}{l}T \subset T \\
S \bullet r\end{array}$ & $\begin{array}{l}\mathbf{A C T} \\
T_{\mathbf{h}} \mathbf{T}\end{array}$ & $\begin{array}{l}\mathbf{A} \text { T } \mathbf{A} \\
\mathrm{I} 1 \mathbf{e}\end{array}$ & $\begin{array}{l}\text { TA T } \\
\text { T y } \mathbf{r}\end{array}$ & $\begin{array}{l}\text { T G G } \\
\text { T } \simeq \text { p } \\
160\end{array}$ & 538 \\
\hline $\begin{array}{l}T C A \\
S \in \mathbb{r}\end{array}$ & $\begin{array}{l}G A G \\
G 1 U\end{array}$ & $\begin{array}{l}\text { GAA } \\
\text { G I U }\end{array}$ & $\begin{array}{l}\text { GAG } \\
G I u\end{array}$ & $\begin{array}{l}\text { C T T } \\
\text { L E v } \\
165\end{array}$ & $\begin{array}{l}C A A \\
\text { G } 1:\end{array}$ & $\begin{array}{l}G A G \\
G 1 \mathrm{U}\end{array}$ & $\begin{array}{l}\text { C T T } \\
\text { L e u }\end{array}$ & $\begin{array}{l}\text { C A A } \\
\text { G } 1 \mathrm{n}\end{array}$ & $\begin{array}{ccc}G & T \\
G & 1 & y \\
1 & 7 & 0\end{array}$ & $\begin{array}{l}T C T \\
S \in T\end{array}$ & $\begin{array}{l}\text { CA A } \\
\text { G } 1 \mathrm{n}\end{array}$ & $\begin{array}{l}\text { C I T } \\
\text { L C U }\end{array}$ & $\begin{array}{l}\text { I T G } \\
L \in U\end{array}$ & 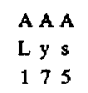 & $\begin{array}{l}\text { ACA } \\
\text { T h I }\end{array}$ & 586 \\
\hline $\begin{array}{l}\mathrm{A} C \mathrm{CA} \\
\mathrm{T} \mathrm{b}_{\mathrm{r}}\end{array}$ & $\begin{array}{l}\text { G T G } \\
\text { V a } 1\end{array}$ & $\begin{array}{l}T C T \\
S \in T\end{array}$ & $\begin{array}{lll}G & T & G \\
V & \text { A } & 1 \\
1 & 8 & 0\end{array}$ & $\begin{array}{l}\mathrm{AAA} \\
\mathrm{LA} \text { \& }\end{array}$ & $\begin{array}{l}\text { OA A } \\
\text { G } 1 \mathrm{u}\end{array}$ & $\begin{array}{l}\text { TA T } \\
\text { T y } \mathbf{r}\end{array}$ & $\begin{array}{l}\text { G I G } \\
\text { V a } 1\end{array}$ & $\begin{array}{l}\text { A A G } \\
\text { L Y s } \\
185\end{array}$ & $\begin{array}{l}\mathrm{AAT} \\
\mathrm{A}: \mathfrak{n}\end{array}$ & $\begin{array}{l}\text { GAA } \\
\text { G } 1 \mathbf{u}\end{array}$ & $\begin{array}{l}\text { T G T } \\
\text { Cys }\end{array}$ & $\begin{array}{l}\text { T T G } \\
L \in U\end{array}$ & $\begin{array}{lll}\text { A A } & A \\
\text { L } & \text { y } & \text { s } \\
1 & 9 & 0\end{array}$ & $\begin{array}{l}\text { C TA } \\
\text { Le U }\end{array}$ & $\begin{array}{l}\text { GA A } \\
\text { G } 1 \text { U }\end{array}$ & 634 \\
\hline $\begin{array}{l}C A A \\
G 1 \mathrm{n}\end{array}$ & $\begin{array}{l}G A A \\
G \perp v\end{array}$ & $\begin{array}{lll}\text { A T C } \\
\text { I } 11 & \text { e } \\
1 & 9 & 5\end{array}$ & $\begin{array}{l}\text { A T T } \\
\text { I l e }\end{array}$ & $\begin{array}{l}C \text { T C } \\
\text { L e v }\end{array}$ & $\begin{array}{lll}\mathbf{C} & \mathbf{C} & \mathbf{T} \\
\mathrm{P} & \mathrm{r} & \mathrm{O}\end{array}$ & $\begin{array}{l}A A T \\
A \& n\end{array}$ & 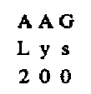 & $\begin{array}{l}\mathrm{CGG} \\
\mathrm{A} \mathrm{rg}\end{array}$ & $\begin{array}{l}\text { CT T } \\
L \in \mathrm{u}\end{array}$ & $\begin{array}{l}\text { T T T } \\
\text { P b c }\end{array}$ & $\begin{array}{l}\text { C C G } \\
P \text { : } 0\end{array}$ & 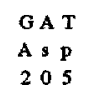 & $\begin{array}{l}\mathrm{C} C \mathrm{~T} \\
\mathrm{P} \text { I }\end{array}$ & $\begin{array}{l}G T G \\
V_{A} 1\end{array}$ & $\begin{array}{l}A C G \\
T b \mathbf{r}\end{array}$ & 682 \\
\hline $\begin{array}{l}C T O \\
L \in 0\end{array}$ & $\begin{array}{ccc}\text { G } & \mathbf{A} & \mathrm{T} \\
\mathbf{A} & \mathbf{s} & \mathbf{p} \\
2 & 1 & 0\end{array}$ & $\begin{array}{l}\text { GAC } \\
\text { A s p }\end{array}$ & $\begin{array}{l}\text { T T C } \\
\text { P b e }\end{array}$ & $\begin{array}{l}\text { T T T } \\
\text { P h e }\end{array}$ & $\begin{array}{l}T G G \\
T \Gamma P\end{array}$ & 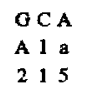 & $\begin{array}{l}\text { I I T } \\
\text { P b e }\end{array}$ & $\begin{array}{l}\text { GGA } \\
\text { G } 1 \mathrm{Y}\end{array}$ & $\begin{array}{l}\text { A T T } \\
\text { I } 1 \text { e }\end{array}$ & $\begin{array}{l}\text { C T C } \\
L \in u\end{array}$ & $\begin{array}{l}A G A \\
A: 8 \\
220\end{array}$ & $\begin{array}{l}T C A \\
S \in \mathbf{r}\end{array}$ & $\begin{array}{l}A G G \\
A r g\end{array}$ & $\begin{array}{l}\mathbf{G C G} \\
A \perp \mathbf{a}\end{array}$ & $\begin{array}{l}\text { T T T } \\
\text { P b e }\end{array}$ & 730 \\
\hline $\begin{array}{lll}T & C & T \\
S & e & T \\
2 & 2 & 5\end{array}$ & $\begin{array}{l}C G C \\
A \times g\end{array}$ & $\begin{array}{l}\text { C T T } \\
L \in \mathbf{U}\end{array}$ & $\begin{array}{l}\mathrm{COC} \\
\mathrm{A} \text { r } 8\end{array}$ & $\begin{array}{l}A \mathrm{AT} \\
\mathrm{A} \& \mathrm{n}\end{array}$ & $\begin{array}{lll}G & A & A \\
G & 1 & u \\
2 & 3 & 0\end{array}$ & $\begin{array}{l}\mathrm{AAT} \\
\mathrm{A}: \mathrm{I}\end{array}$ & $\begin{array}{l}\text { CTG } \\
L \in u\end{array}$ & $\begin{array}{l}G T T \\
V_{\text {a }} \mathbf{T}\end{array}$ & $\begin{array}{l}G \mathrm{~T} G \\
\mathrm{~V}_{\mathrm{a}} 1\end{array}$ & $\begin{array}{lll}\text { G } & \text { T } & \text { T } \\
V & \text { a } & 1 \\
2 & 3 & 5\end{array}$ & $\begin{array}{l}\mathrm{CCA} \\
\mathrm{P}_{\mathrm{I}} \mathrm{O}\end{array}$ & $\begin{array}{l}\mathrm{ATG} \\
M=\mathrm{t}\end{array}$ & $\begin{array}{l}\text { GCA } \\
\text { A l a }\end{array}$ & $\begin{array}{l}\text { GAC } \\
\text { A s p }\end{array}$ & $\begin{array}{l}\text { T T O } \\
L \in u \\
240\end{array}$ & 778 \\
\hline $\begin{array}{l}\text { A T T } \\
\text { I } 1 \text { e }\end{array}$ & $\begin{array}{l}A A C \\
A \text { : }\end{array}$ & $\begin{array}{l}\mathrm{CAC} \\
\mathrm{Hi}\end{array}$ & $\begin{array}{l}\text { AGT } \\
S C T\end{array}$ & 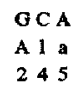 & $\begin{array}{l}\text { GGA } \\
\text { G } 1 y\end{array}$ & $\begin{array}{l}\text { G T T } \\
V_{\text {a }} 1\end{array}$ & $\begin{array}{l}\text { ACT } \\
\text { T h r }\end{array}$ & $\begin{array}{l}A C A \\
T \mathbf{b}_{\mathrm{x}}\end{array}$ & $\begin{array}{lll}0 & A & O \\
O & 1 & 0 \\
2 & 5 & 0\end{array}$ & $\begin{array}{l}\text { GA T } \\
\text { A }: \text { p }\end{array}$ & $\begin{array}{l}\text { CA A T } \\
\text { H i s }\end{array}$ & $\begin{array}{l}\text { GC T } \\
\text { A I }\end{array}$ & $\begin{array}{l}\text { TA T } \\
\text { T Y } I\end{array}$ & 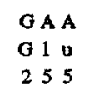 & $\begin{array}{l}G \text { I T } \\
\text { V a } 1\end{array}$ & 826 \\
\hline $\begin{array}{l}A A A \\
L Y \&\end{array}$ & $\begin{array}{l}\text { GGA } \\
\text { G } 1 \text { y }\end{array}$ & $\begin{array}{l}\mathrm{GCA} \\
\mathrm{A} 1 \mathrm{a}\end{array}$ & $\begin{array}{l}\text { G C C T } \\
\text { A } 11 \text { a } \\
260\end{array}$ & $\begin{array}{l}\text { GGC } \\
\text { G } 1 \text { y }\end{array}$ & $\begin{array}{l}\text { C T T } \\
\text { Leu }\end{array}$ & $\begin{array}{l}\text { T T C } \\
\text { P he }\end{array}$ & $\begin{array}{l}\text { TCT } \\
S \text { e }\end{array}$ & $\begin{array}{l}\text { T G G } \\
\mathrm{I} I \mathrm{P} \\
265\end{array}$ & $\begin{array}{l}\text { GAT } \\
\text { A s P }\end{array}$ & $\begin{array}{l}\text { T AC } \\
\text { T } \mathbf{Y} \mathbf{r}\end{array}$ & $\begin{array}{l}C T A \\
L \in v\end{array}$ & $\begin{array}{l}\text { T T T } \\
\text { P b e }\end{array}$ & 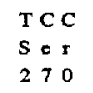 & $\begin{array}{l}\text { T T A } \\
L \in u\end{array}$ & $\begin{array}{l}A A G \\
L y s\end{array}$ & 874 \\
\hline $\begin{array}{l}A G C \\
S E I\end{array}$ & $\begin{array}{l}\mathrm{CCC} \\
\mathrm{Pr}\end{array}$ & $\begin{array}{lll}C & T & T \\
L & e & u \\
2 & 7 & 5\end{array}$ & $\begin{array}{l}T C C \\
S \in\end{array}$ & $\begin{array}{l}\text { G T C } \\
V_{\text {a } 1}\end{array}$ & $\begin{array}{l}A A G \\
L_{Y S}\end{array}$ & $\begin{array}{l}O C C \\
\text { A } 1 \text { a }\end{array}$ & $\begin{array}{lll}G & G & A \\
G & 1 & y \\
2 & 8 & 0\end{array}$ & $\begin{array}{l}\text { GAA } \\
\text { G } 1 \text { u }\end{array}$ & $\begin{array}{l}\mathrm{CAO} \\
\mathrm{O} \mathrm{I}_{\mathrm{n}}\end{array}$ & $\begin{array}{l}C T A \\
L \in u\end{array}$ & $\begin{array}{l}\text { T A T } \\
\text { T y t }\end{array}$ & $\begin{array}{lll}\text { A } & \text { A A } \\
\text { I } & 1 & \text { e } \\
2 & 8 & 5\end{array}$ & $\begin{array}{l}C A A \\
G 1 \text { A }\end{array}$ & $\begin{array}{l}T A T \\
T y_{T}\end{array}$ & $\begin{array}{l}\text { GAT } \\
\text { A S p }\end{array}$ & 922 \\
\hline $\begin{array}{l}\mathrm{T} \\
\mathrm{L}\end{array}$ & $\begin{array}{l}A \text { A C } \\
\text { A S A } \\
290\end{array}$ & $\begin{array}{l}\text { AAA } \\
\text { Ly: }\end{array}$ & $\begin{array}{l}A G C \\
S \in I\end{array}$ & $\begin{array}{l}A A T \\
A: n\end{array}$ & $\begin{array}{l}G C A \\
A 1 A\end{array}$ & $\begin{array}{l}G A G \\
G 11 \\
295\end{array}$ & $\begin{array}{l}\text { T T G } \\
L \in U\end{array}$ & $\begin{array}{l}\text { GCT } \\
\text { A I }\end{array}$ & $\begin{array}{l}C T A \\
L \in u\end{array}$ & $\begin{array}{l}G A C \\
A \& p\end{array}$ & $\begin{array}{lll}T & \mathbf{A} & \mathbf{C} \\
\mathrm{T} & \mathbf{y} & \mathbf{r} \\
\mathbf{3} & \mathbf{0} & \mathbf{0}\end{array}$ & $\begin{array}{l}G G T \\
G 1 y\end{array}$ & $\begin{array}{l}\text { T T C } \\
\text { P b e }\end{array}$ & $\begin{array}{l}\text { AT T } \\
\text { I } 1 \text {. }\end{array}$ & $\begin{array}{l}\text { GAA } \\
\text { G1 }\end{array}$ & 970 \\
\hline $\begin{array}{lll}C & C & A \\
\text { P } & \text { r } & 0 \\
3 & 0 & 5\end{array}$ & $\begin{array}{l}\text { A A T } \\
\text { A s } \mathrm{n}\end{array}$ & $\begin{array}{l}\text { GAA } \\
\text { G } 1 \mathbf{u}\end{array}$ & $\begin{array}{l}A \mathrm{~A} T \\
\mathrm{~A} \& \mathrm{I}\end{array}$ & $\begin{array}{l}C G A \\
A \times B\end{array}$ & $\begin{array}{ccc}\mathrm{C} & \mathbf{A} & \mathrm{T} \\
\mathrm{H} & \mathrm{i} & \mathrm{s} \\
3 & \mathbf{1} & 0\end{array}$ & $\begin{array}{l}\mathrm{OCA} \\
\mathrm{A} 1 \mathrm{a}\end{array}$ & $\begin{array}{l}\text { TAC } \\
\text { T Y I }\end{array}$ & $\begin{array}{l}\text { ACT } \\
\text { T b r }\end{array}$ & $\begin{array}{l}\text { C T G } \\
\text { Le u }\end{array}$ & $\begin{array}{lll}A & C & G \\
1 & h & I \\
3 & 1 & 5\end{array}$ & $\begin{array}{l}\text { C T G } \\
\text { Lev }\end{array}$ & $\begin{array}{l}\text { GAG } \\
G 1 \mathrm{u}\end{array}$ & $\begin{array}{l}\text { A T A } \\
\text { I } 1 \text { e }\end{array}$ & $\begin{array}{l}T \subset T \\
S \in I\end{array}$ & $\begin{array}{lll}G & A & G \\
G & 1 & u \\
3 & 2 & 0\end{array}$ & 1018 \\
\hline $\begin{array}{l}T \subset G \\
S \in T\end{array}$ & $\begin{array}{l}\text { OAC } \\
\text { A s p }\end{array}$ & $\begin{array}{lll}\mathrm{C} & \mathrm{C} & \mathrm{T} \\
\mathrm{P} & \mathrm{r} & \mathrm{O}\end{array}$ & $\begin{array}{l}\text { T T T } \\
\text { P h e }\end{array}$ & $\begin{array}{l}\text { T T T } \\
\text { P he } \\
325\end{array}$ & $\begin{array}{l}\text { G A T } \\
\mathbf{A}: \mathrm{p}\end{array}$ & $\begin{array}{l}G A C \\
A \& P\end{array}$ & $\begin{array}{l}\text { A A A } \\
\text { Ly } \mathrm{s}\end{array}$ & $\begin{array}{l}\text { CTA } \\
\text { Lev }\end{array}$ & $\begin{array}{l}G A C \\
A: P \\
3 \text { 3 } 0\end{array}$ & $\begin{array}{l}\text { GT T } \\
\mathrm{V} \text { a } 1\end{array}$ & $\begin{array}{l}\text { GCT } \\
\text { A } 1 \text { a }\end{array}$ & $\begin{array}{l}G A G \\
G \perp \mathfrak{u}\end{array}$ & $\begin{array}{l}\text { TCC } \\
S \in \mathrm{r}\end{array}$ & 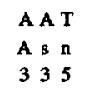 & $\begin{array}{l}\text { GOT } \\
\text { G1 y }\end{array}$ & 1066 \\
\hline $\begin{array}{l}\text { T I T } \\
\text { P b e }\end{array}$ & $\begin{array}{l}G C T \\
\text { A I a }\end{array}$ & $\begin{array}{l}C A G \\
G 1 \text { I }\end{array}$ & $\begin{array}{l}A C A \\
\text { T h r } \\
340\end{array}$ & $\begin{array}{l}\text { GCG } \\
\text { A } 1 \text { a }\end{array}$ & $\begin{array}{l}\text { T A C } \\
\text { T Y } \mathbf{T}\end{array}$ & $\begin{array}{l}\text { T T T } \\
\text { P h e }\end{array}$ & $\begin{array}{l}G A C \\
A \& P\end{array}$ & $\begin{array}{l}\text { A T C } \\
11 \text { C } \\
345\end{array}$ & $\begin{array}{l}\text { T TC } \\
\text { P be }\end{array}$ & $\begin{array}{l}\text { TAT } \\
\text { T } \mathbf{Y}:\end{array}$ & $\begin{array}{l}\text { A A T } \\
\text { A s n }\end{array}$ & $\begin{array}{l}\mathrm{CGC} \\
\mathrm{A} \pm \mathrm{g}\end{array}$ & $\begin{array}{l}\text { A C T } \\
\text { T b I } \\
350\end{array}$ & $\begin{array}{l}\text { C T T } \\
L \in U\end{array}$ & $\begin{array}{l}\mathrm{CCA} \\
\mathrm{P} \text { r } 0\end{array}$ & 1114 \\
\hline $\begin{array}{l}\mathrm{CCT} \\
\mathrm{PI} \quad\end{array}$ & $\begin{array}{l}\text { G GA } \\
G 1 y\end{array}$ & $\begin{array}{l}\text { T T G } \\
\mathrm{L} \in \mathrm{u} \\
355\end{array}$ & $\begin{array}{l}C T \\
L \\
L\end{array}$ & $\begin{array}{l}\mathrm{CCA} \\
\mathrm{P}_{\mathrm{r}} \mathrm{O}\end{array}$ & $\begin{array}{l}\text { T A T } \\
\text { T Y } \mathrm{T}\end{array}$ & $\begin{array}{l}\text { C T G } \\
L \bullet u\end{array}$ & $\begin{array}{l}A G A \\
A \times g \\
360\end{array}$ & $\begin{array}{l}\mathrm{CT} T \\
\mathrm{~L} \in \mathrm{u}\end{array}$ & $\begin{array}{l}\text { G I A } \\
V_{a} 1\end{array}$ & $\begin{array}{l}\text { OCG } \\
\text { Ala }\end{array}$ & $\begin{array}{l}C T A \\
L \in u\end{array}$ & $\begin{array}{l}G G G \\
G 1 y \\
365\end{array}$ & $\begin{array}{l}G G T \\
\text { G } 1 y\end{array}$ & $\begin{array}{l}\text { ACC } \\
T_{\text {b }}\end{array}$ & $\begin{array}{l}\text { GAC } \\
\text { Asp }\end{array}$ & 1162 \\
\hline $\begin{array}{l}\text { GCT } \\
\text { A I a }\end{array}$ & $\begin{array}{l}\text { T T C } \\
P \text { h e } \\
370\end{array}$ & $\begin{array}{l}T \text { T A } \\
L \in A\end{array}$ & $\begin{array}{l}\text { T T G } \\
\text { Le U }\end{array}$ & $\begin{array}{l}\text { GAA } \\
\text { GIU }\end{array}$ & $\begin{array}{l}T C A \\
S \in x\end{array}$ & $\begin{array}{l}C T G \\
L \in u \\
375\end{array}$ & $\begin{array}{l}\text { T T C } \\
\text { P b e }\end{array}$ & $\begin{array}{l}A G A \\
A \times B\end{array}$ & $\begin{array}{l}\text { GAC } \\
\text { A s p }\end{array}$ & $\begin{array}{l}A C C \\
T \text { b } ~\end{array}$ & $\begin{array}{l}\text { A T A } \\
111 \text { e } \\
3810\end{array}$ & $\begin{array}{l}\mathbf{T G G} \\
\mathbf{T} \mathbf{T} \mathbf{p}\end{array}$ & $\begin{array}{l}G G T \\
G 1 y\end{array}$ & 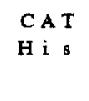 & $\begin{array}{l}\text { CT T } \\
\text { Le }\end{array}$ & 1210 \\
\hline $\begin{array}{lll}G & A & G \\
G & 1 & u \\
3 & 8 & 5\end{array}$ & $\begin{array}{l}\text { T T G } \\
\text { L } \in U\end{array}$ & $\begin{array}{l}T \subset T \\
S \in I\end{array}$ & $\begin{array}{l}\text { G T C } \\
\text { V a }\end{array}$ & $\begin{array}{l}A G C \\
S \in r\end{array}$ & $\begin{array}{c}C G T \\
A \times g \\
390\end{array}$ & $\begin{array}{l}G A C \\
A \subseteq p\end{array}$ & $\begin{array}{l}\text { A A T } \\
\text { A : } \mathrm{n}\end{array}$ & $\begin{array}{l}\text { G AG } \\
\text { G } 1 \text { u }\end{array}$ & $\begin{array}{l}G A G \\
G 1:\end{array}$ & $\begin{array}{l}C T A \\
L \in v \\
395\end{array}$ & $\begin{array}{l}\text { CTA } \\
\text { L } A ~\end{array}$ & $\begin{array}{l}\text { TOC } \\
\text { Cys }\end{array}$ & $\begin{array}{l}\text { A A A } \\
\text { L y s }\end{array}$ & $\begin{array}{l}\mathrm{GCC} \\
\mathrm{A} 1 \mathrm{a}\end{array}$ & $\begin{array}{lll}G & T & T \\
V & a & 1 \\
4 & 0 & 0\end{array}$ & 1258 \\
\hline $\begin{array}{l}C G A \\
A \times \mathbf{B}\end{array}$ & $\begin{array}{l}\text { GAA } \\
\text { G } 1 \mathrm{u}\end{array}$ & $\begin{array}{l}G C C \\
\text { A } 1 \text { a }\end{array}$ & $\begin{array}{l}T G C \\
C y s\end{array}$ & $\begin{array}{l}\text { A A A } \\
\text { L y s } \\
405\end{array}$ & $\begin{array}{l}T C T \\
S \in I\end{array}$ & $\begin{array}{l}\text { GCC } \\
\text { Alla }\end{array}$ & $\begin{array}{l}\text { C T T } \\
\text { L e u }\end{array}$ & $\begin{array}{l}\text { GCT } \\
\text { A I a }\end{array}$ & $\begin{array}{l}\text { GG T } \\
01 \mathrm{y} \\
410\end{array}$ & $\begin{array}{l}\text { T A T } \\
\text { T y r }\end{array}$ & $\begin{array}{l}\text { CAT } \\
\text { His }\end{array}$ & $\begin{array}{l}\text { A CA } \\
\text { T h } \mathrm{r}\end{array}$ & $\begin{array}{l}A C C \\
T \text { b } x\end{array}$ & $\begin{array}{lll}\text { A } & \text { T } & \text { T } \\
\text { I } & 1 & \text { E } \\
4 & 1 & 5\end{array}$ & $\begin{array}{l}\text { GAA } \\
\text { G } 1 \mathbf{~}\end{array}$ & 1306 \\
\hline $\begin{array}{l}\mathrm{CAG} \\
\mathrm{G} 1 \mathrm{a}\end{array}$ & $\begin{array}{l}\text { GAT } \\
\text { A } \quad \text { S P }\end{array}$ & $\begin{array}{l}\mathrm{CGC} \\
\mathrm{A} \times \mathrm{B}\end{array}$ & $\begin{array}{l}G A G \\
G 11 \\
420\end{array}$ & $\begin{array}{l}\text { T T G } \\
L \in u\end{array}$ & $\begin{array}{l}A A A \\
L_{y A s}\end{array}$ & $\begin{array}{l}\text { GAA } \\
\text { G1 }\end{array}$ & $\begin{array}{l}\text { GOA } \\
\text { GIy }\end{array}$ & $\begin{array}{l}\text { A A T } \\
\text { A } \$ \text { n } \\
425\end{array}$ & $\begin{array}{l}C T A \\
L \in 0\end{array}$ & $\begin{array}{l}\text { G A T } \\
\mathbf{A} \leq \mathbf{p}\end{array}$ & $\begin{array}{l}\text { TCA } \\
\text { Sex }\end{array}$ & $\begin{array}{l}A G G \\
A \mp g\end{array}$ & $\begin{array}{l}C T T \\
\text { L }=1 \\
430\end{array}$ & $\begin{array}{l}\text { OCA } \\
\text { A } 1 \text { a }\end{array}$ & $\begin{array}{l}\text { A T A } \\
\text { I } 1 \text { e }\end{array}$ & 1354 \\
\hline $\begin{array}{l}\text { GCA } \\
\text { A } 1 \text { a }\end{array}$ & $\begin{array}{l}\text { G T T } \\
\text { V a } 1\end{array}$ & $\begin{array}{l}\mathbf{G G A} \\
\mathbf{G} 1 \mathbf{y}\end{array}$ & $\begin{array}{l}\text { A T A } \\
\text { I } 1 \text { e }\end{array}$ & $\begin{array}{l}A G A \\
A \subseteq B\end{array}$ & $\begin{array}{l}\text { GA A } \\
G 1 \mathrm{U}\end{array}$ & $\begin{array}{l}G G G \\
G 1 y\end{array}$ & $\begin{array}{l}G A A \\
G 1 \cup\end{array}$ & $\begin{array}{l}A A G \\
L y s\end{array}$ & $\begin{array}{l}\text { ATG } \\
M \in t\end{array}$ & $\begin{array}{l}\text { G T C } \\
\mathrm{V} \mathrm{a} \mathrm{I} \mathrm{I}^{2}\end{array}$ & $\begin{array}{l}\text { C T G } \\
L \in u\end{array}$ & $\begin{array}{l}C A G \\
G 1 \mathbf{n}\end{array}$ & $\begin{array}{l}C A A \\
G 1 \mathrm{n}\end{array}$ & $\begin{array}{l}\text { A T T } \\
\text { I } 1 \text { e }\end{array}$ & $\begin{array}{l}\text { GAC } \\
\text { A \& }\end{array}$ & 1402 \\
\hline
\end{tabular}




\section{$5,723,752$}

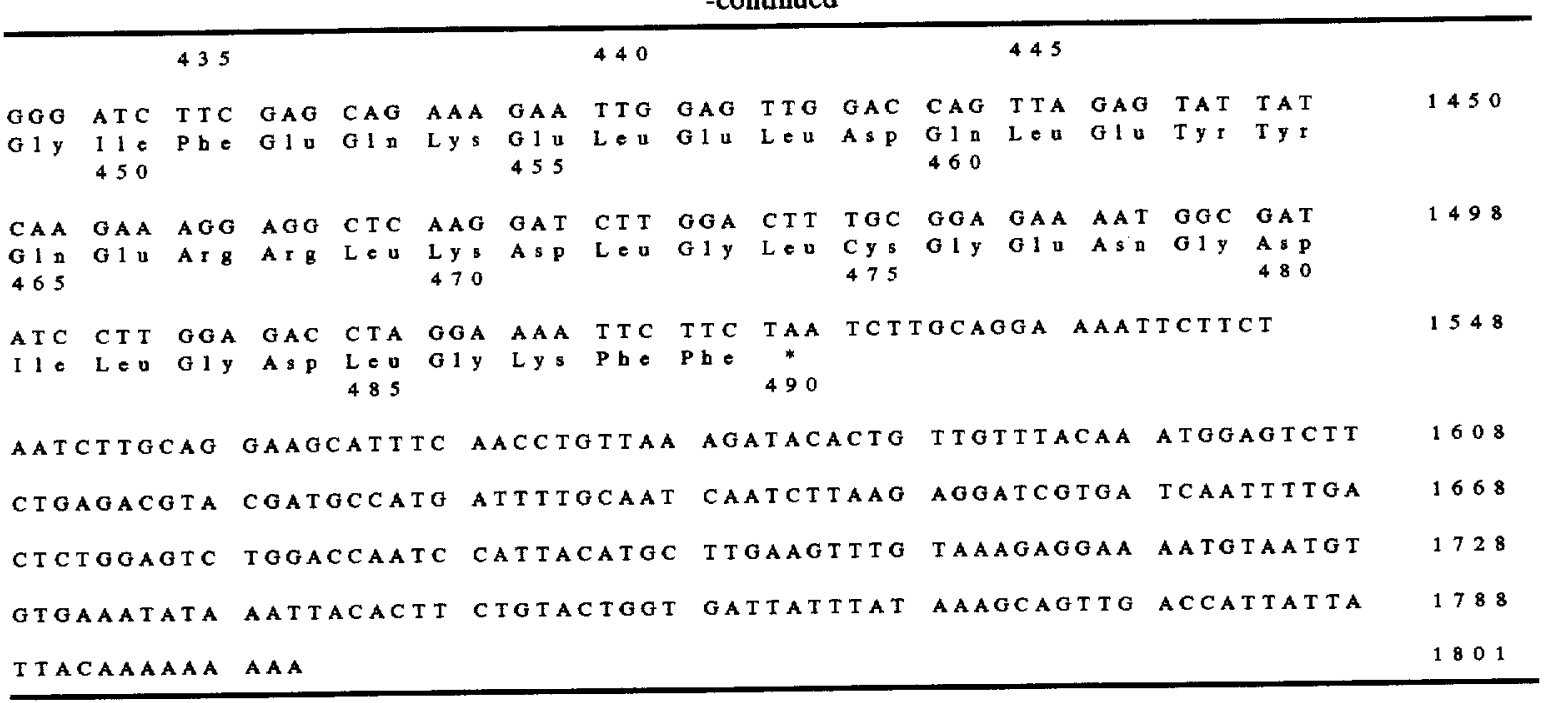

What is claimed is:

1. An isolated Rubisco LSMT gene which is expressed in a photosynthesizing plant having a large subunit of Rubisco and which encodes a Rubisco LSMT enzyme.

2. The isolated Rubisco LSMT gene of claim 1, wherein said enzyme catalyzes methylation of the $\epsilon$-amine of lysine 14 in the large subunit of Rubisco.

3. The isolated gene of claim 1, wherein said photosynthesizing plant is selected from the group consisting of pea. soybean. tomato, potato, tobacco, pepper cucumber, melon and gourd.

4. The isolated gene of claim 3. wherein said plant is pea.

5. A recombinant vector comprising the Rubisco LSMT gene of claim 1, said vector being one which can transform a photosynthesizing plant.

6. A method for expressing a Rubisco LSMT gene in a plant comprising transforming a plant with the Rubisco LSMT gene of claim 1, said plant thereby expressing the Rubisco LSMT enzyme encoded by said Rubisco LSMT gene.

7. A recombinant photosynthesizing non-pea plant transformed with the Rubisco LSMT gene of claim 1.
8. The recombinant plant of claim 7; wherein said Rubisco LSMT gene expresses said Rubisco LSMT enzyme.

9. The recombinant plant of claim 8 , wherein said Rubisco LSMT enzyme catalyzes methylation of an $\epsilon$-amine of lysine-14 in the large subunit of Rubisco.

10. The recombinant plant of claim 9, wherein said plant 30 is selected from the group consisting of a soybean, tomato, potato, tobacco. pepper, cucumber, melon and gourd.

11. A method for transforming a plant comprising inserting said vector of claim 5 , into a plant.

12. A recombinant photosynthesizing non-pea plant transformed with the vector of claim 5 .

13. The isolated gene of claim 1, wherein said photosynthesizing plant is a legume.

14. The recombinant plant of claim 9, wherein said plant 40 is a legume.

15. An isolated cDNA having the sequence of SEQ. ID NO. 41 . 


\section{UNITED STATES PATENT AND TRADEMARK OFFICE CERTIFICATE OF CORRECTION}

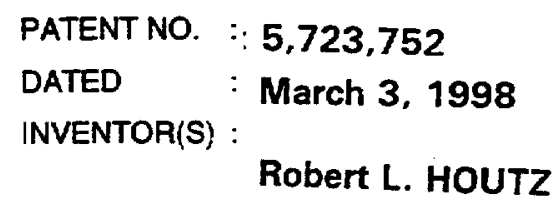

Robert L. HOUTZ

It is certified that error appears in the above-identified patent and that said Letters Patent is hereby corrected as shown below:

The title page, showing "4 Drawing Sheets" should be --7 Drawing Sheets--.

\section{IN THE DRAWINGS:}

Add the Drawing Sheet consisting of Figs. 3, 4 and 5, as shown on the attached pages.

Signed and Sealed this

Twentieth Day of February, 2001

Attest:

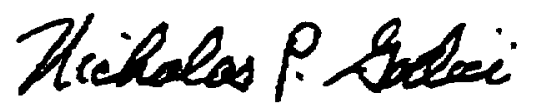

NICHOLAS P. GODICI 


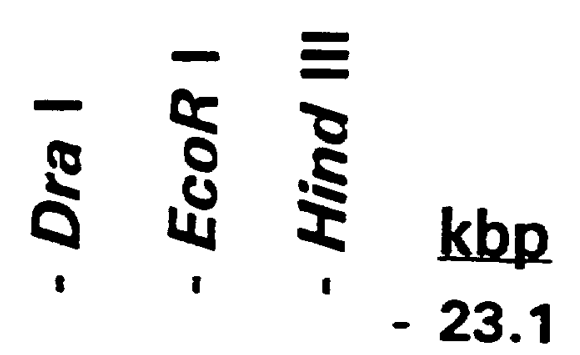

- 9.4

- 6.6

- 4.4

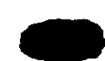

$\longrightarrow$

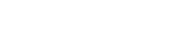

- 2.3

$\rightarrow \quad-2.0$

- 0.6

Figure 3 


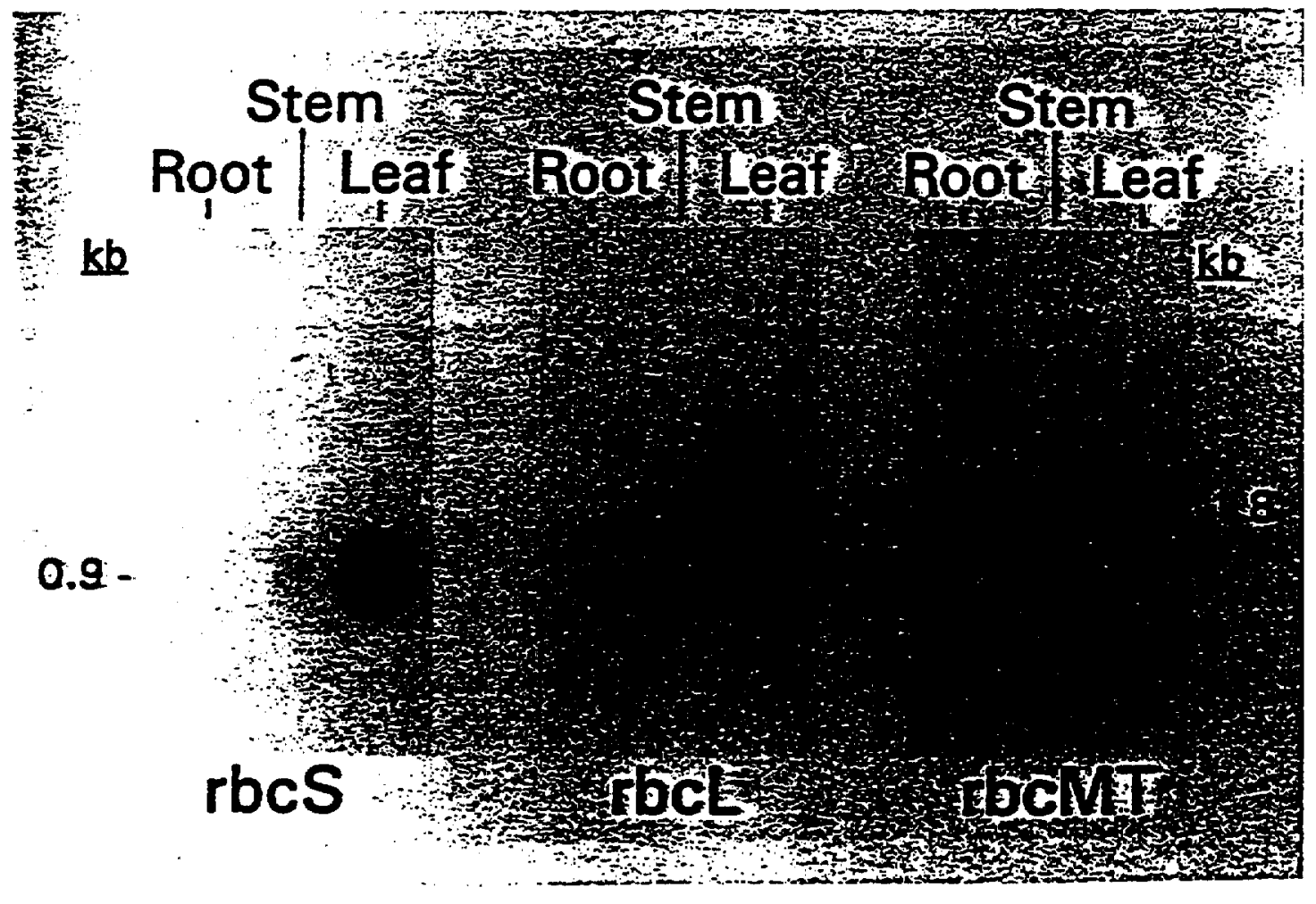

Figure 4 


\section{U.S. Patent

\section{Light Treatment}

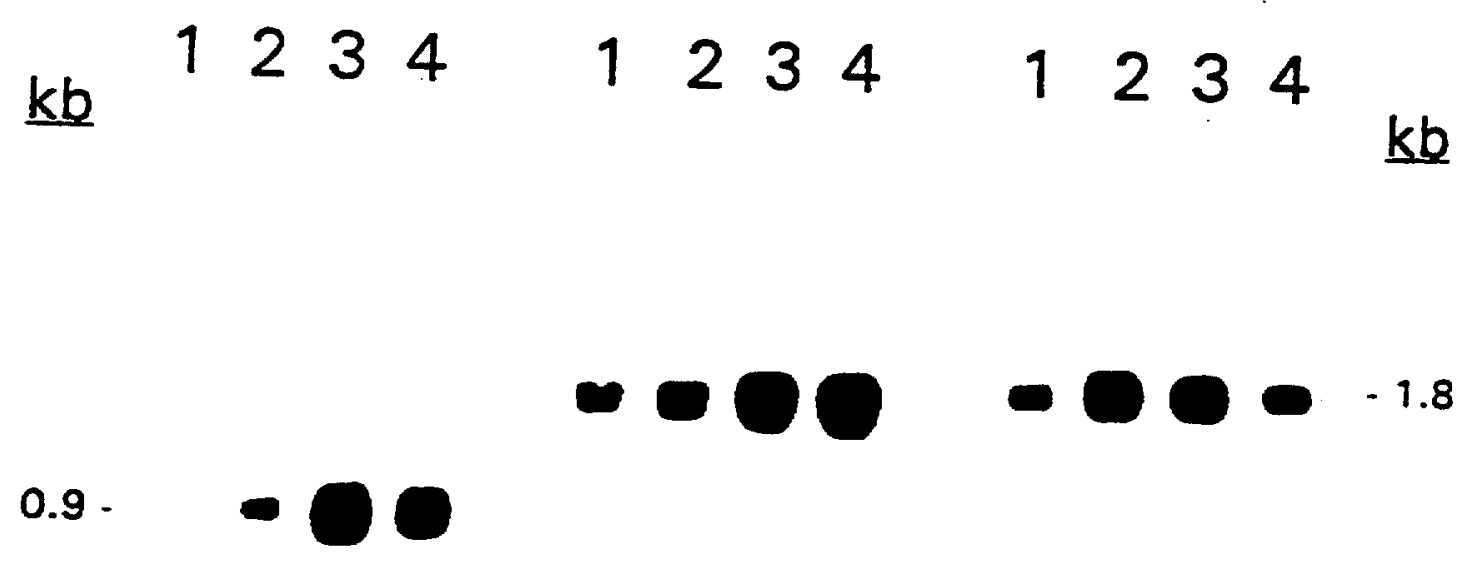

rbcs

$\mathrm{rbcL}$

rbcMT

Figure 5 